\title{
BADANIA INSTYTUTU PRAHISTORII UAM W POZNANIU NA TELL ARBID (PÓŁNOCNO-WSCHODNIA SYRIA) W LATACH 2008-2009
}

\author{
TWO SEASONS OF EXCAVATIONS AT TELL ARBID \\ (NORTH-EAST SYRIA), 2008-2009
}

\section{Rafał Koliński}

Instytut Prahistorii, Uniwersytet im. Adama Mickiewicza ul. Św. Marcin 78, 61-809 Poznań, Poland

\begin{abstract}
In 2008 a new research project has been launched by the Institute of Prehistory, Adam Mickiewicz University of Poznan in the framework of Polish-Syrian Archaeological Mission to Tell Arbid. The objective of the project is to make extensive clearance of the remains identified previously in Sector SR at Tell Arbid as belonging to the post-Akkadian period (ca. 2150-2000 BC), a period of alleged abandonment and cultural collapse in the north-eastern part of Syria.

Two seasons of fieldwork resulted in extensive exposure of the post-Akkadian structures, including several buildings, household and industrial installations (pottery kiln) as well as some graves. Among the findings, a considerable number of copper/bronze tools, implements and jewelry pieces are worth mentioning; the presence of numerous artifacts of copper/bronze and of a sandstone casting mould is suggestive of presence of a foundry at the site.

Beside the post-Akkadian remains, an overlying level belonging to Habur Ware period (ca 1800-1700 BC) was explored. It featured mainly foundations of houses as well as a considerable number of graves dug into the surface of the tell. Among the graves, three family chamber graves stand out, because of their well-preserved construction, including a vaulted chamber, and an entrance shaft protected by a retention wall. One of these graves yielded a rich set of burial gifts, including weapons and other implements of copper/bronze, more than dozen pottery vessels and over 200 beads, as well as some semi-precious stones. Work at the site will be continued in 2010.
\end{abstract}

\section{TELL ARBID}

\section{Położenie i topografia}

Tell Arbid to wzgórze osadnicze (tell) położone w równinnej, stepowej części północno-wschodniej Syrii, w regionie zwanym często Trójkątem Chaburskim. Jego nazwa wywodzi się od najważniejszej rzeki tej części kraju, Chaburu, która wypływa ze źródeł 
położonych w rejonie granicy turecko-syryjskiej i wpada do Eufratu ok. $320 \mathrm{~km}$ dalej na południe. Dolina Chaburu i jedynego jego stałego dopływu Dżaghdżaghu tworzą dwa ramiona wspomnianego trójkąta, natomiast trzeci stanowi położone na północy, już w Turcji, pasmo górskie Tur Abdin. Teren Trójkąta Chaburskiego poprzecinany jest szeregiem biegnących z północy na południe płytkich dolin okresowych strumieni. Tell Arbid położony jest we wschodniej części Trójkąta Chaburskiego, w płytkiej dolinie

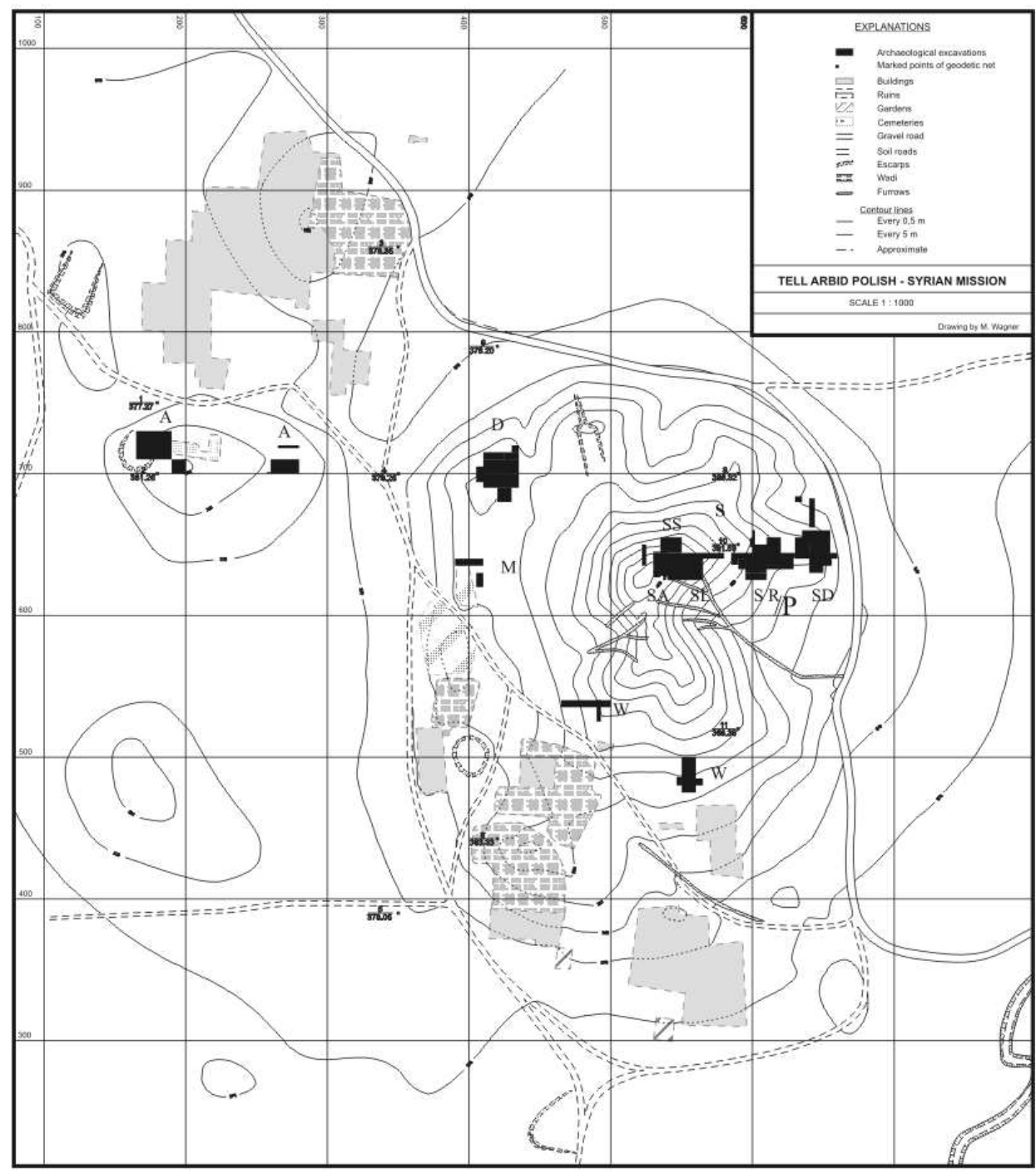

Ryc. 1. Plan warstwicowy stanowiska Tell Arbid pokazujący położenie sektorów wykopaliskowych (rys. M. Wagner) Fig. 1. Contour plan of Tell Arbid showing the location of excavated sectors (drawn by M. Wagner) 
anonimowego, okresowego strumienia, którego koryto przebiega obecnie ok. $200 \mathrm{~m}$ na wschód od stanowiska, ale zaobserwowane wiosną 2009 r. crop marks wskazują, że kiedyś strumień przepływał u stóp tellu.

Stanowisko archeologiczne obejmuje teren ok. 25 do 30 ha i składa się nań właściwy Tell Arbid: prostokątny tell o wymiarach ok. 400 na 250 m (ryc. 1). Jego wysokość w północnej części wynosi ok. $10 \mathrm{~m}$ ponad otaczającą równinę, a płaska powierzchnia opada stopniowo ku południowi; tam wynosi tylko ok. $4 \mathrm{~m}$. W północnej i centralnej części wzgórza ulokowana jest „,cytadela”, L-kształtne wzgórze o ramionach skierowanych ku wschodowi i południowi. Jego niemal poziome północne ramię wznosi się na $25 \mathrm{~m}$ nad otaczający stanowisko step. Po zachodniej stronie głównego tellu, w odległości od 150 do $250 \mathrm{~m}$, zlokalizowane są trzy płaskie wzgórza o wysokości ok. 4-5 m każde. Południowe jest $\mathrm{w}$ znacznym stopniu rozorane, północne natomiast przykrywają zabudowania współczesnej wioski Tell Arbid Fawkani. Wydaje się, że przestrzeń między głównym tellem a wzgórzami satelitarnymi była okazjonalnie wykorzystywana pod zabudowę, podobnie jak teren na wschód od głównego tellu, do koryta okresowego strumienia.

\section{Historia badań}

Stanowisko zostało zarejestrowane przez Sir Maxa Mallowana, który jako pierwszy Europejczyk prowadził systematyczne badania na terenie Trójkąta Chaburskiego w 1935 r. Ukształtowanie i wysokość stanowiska zachęciły go do przeprowadzenia na stanowisku 5-tygodniowych badań sondażowych w maju i czerwcu $1936 \mathrm{r}$. W tym czasie wykopano siedem sondaży, ulokowanych $\mathrm{w}$ różnych częściach stanowiska ${ }^{1}$, ale mimo interesujących znalezisk badań na Tell Arbid nie kontynuowano, koncentrując się na dających znacznie bardziej spektakularne wyniki pobliskich stanowiskach Tell Chagar Bazar i Tell Brak.

Oczywiste walory stanowiska - jego wielkość, morfologiczne zróżnicowanie, a także fakt, że na jego powierzchni niemal nie występowała ceramika późniejsza niż połowa II tysiąclecia p.n.e., spowodowały, że zainteresowali się nim polscy archeolodzy z Centrum Archeologii Śródziemnomorskiej UW, prowadzący od 1988 r. badania ratownicze w tej części Syrii. W roku 1996, w 60 lat po badaniach Mallowana, świeżo ukonstytuowana Polsko-Syryjska Misja Archeologiczna na Tell Arbid przeprowadziła pierwszy sezon badań wykopaliskowych na stanowisku. Do tej pory odbyło się czternaście sezonów misji kierowanej przez prof. dr. hab. Piotra Bielińskiego z UW². Okazjonalnie brali

\footnotetext{
${ }^{1}$ Mallowan 1937, s. 117, 126, 127; Koliński 2007a.

${ }^{2}$ Wstępne raporty z tych badań publikowane są w biuletynie Centrum Archeologii Śródziemnomorskiej UW: „Polish Archaeology in the Mediterranean”, począwszy od roku 1996 (t. X).
} 
w nich udział archeolodzy i studenci IP UAM (w latach 1999, 2001, 2002, 2005). W roku 2008 pracę w ramach koncesji wykopaliskowej UW rozpoczęła kierowana przez autora raportu misja IP UAM.

\section{Historia stanowiska (tab. 1)}

Najstarsze warstwy osadnicze odkryte zostały w obrębie głównego tellu i pochodzą z drugiego i trzeciego stulecia III tysiąclecia p.n.e. (okres kultury Niniwa V) ${ }^{3}$. Cały obszar głównego tellu zajęty był przez stłoczone domy mieszkalne, komunikację między którymi zapewniały wąskie uliczki. W południowej części stanowiska (sektor W) zidentyfikowano niewielką świątynię, wzniesioną na wysokiej na ok. $3 \mathrm{~m}$ platformie. Wokół niej znajdowały się pomieszczenia magazynowe i, prawdopodobnie, warsztaty, co wskazuje, że świątynia oprócz roli kultowej stanowiła także ośrodek życia ekonomicznego. Osada na Tell Arbid, zamieszkana przez ok. 2000 osób i zajmująca ok. 10 ha powierzchni, była zapewne lokalnym centrum, sprawującym kontrolę nad niewielkim terytorium położonym wzdłuż strumienia płynącego dnem doliny. W połowie III tysiąclecia osada zajmuje ten sam obszar, natomiast traci niezależność i zostaje zapewne włączona do terytorium leżącego ok. $25 \mathrm{~km}$ na południe miasta Nagar. Na najwyższej części tellu powstaje w tym okresie budowla administracyjna, niebędąca jednak pałacem królewskim. W tym okresie na zachód i wschód od osady prowadzono do produkcję ceramiczną, o czym świadczą piece ceramiczne i pochodzące z nich odpady.

Tabela 1. Sekwencja chronologiczna osadnictwa na Tell Arbid Table 1. Stratigraphical sequence of Tell Arbid

\begin{tabular}{|l|l|l|l|l|}
\hline \multicolumn{1}{|c|}{$\begin{array}{c}\text { Okres } \\
\text { Tell Arbid }\end{array}$} & \multicolumn{1}{|c|}{ Okres kulturowy } & \multicolumn{1}{c|}{$\begin{array}{c}\text { Okres } \\
\text { archeologiczny }\end{array}$} & Data (p.n.e.) & \multicolumn{1}{c|}{ Sektory } \\
\hline VIIc & Niniwa V & Early Jazireh I-II & $2900-2600$ & D, M, S, SD, W \\
\hline VIIb & wczesnodynastyczny III & Early Jazireh III & $2600-2350$ & D, SD, SS \\
\hline VIIa & akadyjski & Early Jazireh IV & $2350-2150$ & D, SD, SS \\
\hline VI & postakadyjski & Early Jazireh V & $2150-2000$ & SL, SR/P \\
\hline V & staroasyryjski & Old Jazierh I & $2000-1800$ & D, SA, P \\
\hline V & ceramiki chaburskiej & Old Jazireh II-III & $1800-1500$ & D, M, SA, SR/P \\
\hline IVc & mitannijski & Late Bronze Age & $1500-1300$ & A, SA \\
\hline III & nowoasyryjski & Iron Age IIA & $800-600$ & A \\
\hline III & postasyryjski & Iron Age IIB & $600-500$ & A \\
\hline II & hellenistyczny & Iron Age III & $300-100$ & A, D \\
\hline
\end{tabular}

${ }^{3}$ Pojedyncze skorupy ceramiki Halaf pojawiające się w późniejszych warstwach mogą sugerować obecność wczesnochalkolitycznej osady pod nawarstwieniami z epoki brązu. 
W drugiej części III tysiąclecia p.n.e. osada zaczęła tracić na znaczeniu. Południowa i zachodnia część stanowiska została opuszczona już na początku okresu akadyjskiego. Budowla administracyjna na szczycie tellu była jeszcze używana, ale w okresie postakadyjskim na jej miejscu wzniesiono domy. Domy z tego okresu zlokalizowane były także we wschodniej części tellu i, być może, na północy.

Początek II tysiąclecia p.n.e. nie pozostawił prawie żadnych pozostałości architektonicznych, reprezentowany jest przez warstwy o dużej zawartości popiołu i groby. W tym czasie osiedle pełniło zapewne rolę stacji na drodze karawanowej z Asyrii do Anatolii, o czym może świadczyć znaleziony w 1999 r. fragment tabliczki staroasyryjskiej. Na jej podstawie J. Eidem ${ }^{4}$ zaproponował identyfikację stanowiska ze znanym z tekstów miastem Amaz, ale nie została ona udowodniona. W XVIII w. p.n.e. północna i centralna część głównego tellu zostaje zabudowana domami mieszkalnymi tworzącymi rozrzucone skupiska, wokół których koncentrowały się groby zamieszkujących domy ludzi.

W połowie II tysiąclecia p.n.e. osadnictwo przenosi się z głównego tellu na płaski teren położony ok. $150 \mathrm{~m}$ na północny zachód. W okresie mitannijskim tam powstają domy. Na szczycie cytadeli odkryto tylko jamy, pozostałości po instalacjach (piece, zbiornik z kolektorem płynów) oraz dwa groby komorowe.

Podobnie wygląda sytuacja w I tysiącleciu p.n.e. Pozostałości okresu nowoasyryjsiego to ceramika znaleziona w bruku ułożonym na dziedzińcu rozległej budowli z okresu po upadku Asyrii na skutek najazdu Babilończyków i Medów w 612 r. p.n.e. Wreszcie, w okresie hellenistycznym, na ruinach starszych budowli wzniesiono obszerną farmę zajmującą centralne z zachodnich wzgórz. W tym okresie północną część głównego tellu wykorzystywano jako cmentarzysko. U schyłku I w. p.n.e. stanowisko zostało opuszczone, a ludzie pojawili się na nim w 2000 lat później, gdy ok. 1920 r. powstała wieś Arbid Tahtani.

\section{PROJEKT INSTYTUTU PRAHISTORII UAM NA TELL ARBID}

W maju 2008 r. odbył się pierwszy sezon badań na Tell Arbid prowadzonych przez Instytut Prahistorii UAM w ramach polsko-syryjskiej koncesji wykopaliskowej, której posiadaczem jest Centrum Archeologii Śródziemnomorskiej UW i biorą w nich udział archeolodzy i studenci z IP UAM, Centrum Archeologii Śródziemnomorskiej UW oraz przedstawiciele syryjskiego Departamentu Starożytności i Muzeów (DGAM).

\section{Cel projektu}

Pozostałości postakadyjskie znaleziono na Tell Arbid na szczycie tellu, ale poza bogatą kolekcją ceramiki ${ }^{5}$ (która wystąpiła zresztą w niewielkich ilościach i w innych czę-

\footnotetext{
${ }^{4}$ Eidem 2008, s. 40, 41.

${ }^{5}$ Opracowanej przez dr. Łukasza Rutkowskiego z IA UW: Rutkowski 2006.
} 
ściach głównego tellu) nie udało się pozyskać danych umożliwiających zbadanie charakteru osady. Odsłonięto co prawda pozostałości dwóch warstw architektonicznych, ale były one na tyle zniszczone przez erozję i późniejszą działalność człowieka (kopanie jam), że nie udało się odtworzyć nawet fragmentarycznego planu zabudowy.

W trakcie badań prowadzących w 2001 r. w sektorze SR, we wschodniej części głównego tellu, w dwóch sondażach natrafiono na pozostałości postakadyjskie: dobrze zachowany piec chlebowy $\mathrm{z}$ trzema kompletnymi naczyniami w środku oraz stojące do wysokości ponad $1 \mathrm{~m}$ mury z cegły suszonej tworzące zarys dwóch prostokątnych pomieszczeń. W tej sytuacji autor raportu postanowił wznowić wykopaliska w sektorze SR (którego nazwę zmieniono na Sektor P), gdzie odsłonięto wcześniej domy z warstwy należącej do okresu ceramiki chaburskiej (XVIII-XVII w. p.n.e.). Było to możliwe dzięki otrzymaniu grantu badawczego N 109398333 Ministerstwa Nauki i Szkolnictwa Wyższego RP, który zapewnił środki na przeprowadzenie trzech sezonów prac polowych ${ }^{6}$.

Cel projektu został zdefiniowany następująco:

- na maksymalnie dużej powierzchni odsłonić pozostałości zabudowy postakadyjskiej, by móc ustalić charakter osadnictwa,

- pozyskać stratyfikowane zespoły zabytków z okresu postakadyjskiego, by móc zweryfikować wnioski wyciągnięte na podstawie często zaburzonego materiału ceramicznego ze szczytu tellu,

- pozyskać próbki zoologiczne (kości zwierzęce) i biologiczne (makroszczątki) w celu przeprowadzenia analiz, które pozwoliłyby zająć stanowisko w dyskusji nad zaistnieniem kryzysu osadniczego spowodowanego kataklizmem ekologicznym, którego zasięg zdaniem amerykańskiego archeologa $\mathrm{H}$. Weissa objął znaczną część północnej półkuli Ziemi ${ }^{7}$.

Do tej pory przeprowadzono dwa sezony polowe. W $2008 \mathrm{r}$. prace trwały zaledwie 3 tygodnie (od 10 czerwca do 3 lipca) ${ }^{8}$. Ich celem było otworzenie szeregu nowych kwadratów $10 \times 10 \mathrm{~m}$ w południowej części Sektora P (ryc. 2) oraz zbadanie warstwy podpowierzchniowej i ewentualnych pozostałości $\mathrm{z}$ okresu ceramiki chaburskiej. W sezonie 2009 r., który trwał od 6 maja do 20 czerwca $^{9}$, kontynuowano eksplorację

\footnotetext{
${ }^{6} \mathrm{~W}$ działalności polowej misja IP UAM korzystała też ze wsparcia finansowego władz UAM, Fundacji na rzecz Nauki Polskiej, Fundacji Uniwersytetu im. Adama Mickiewicza (rok 2009), oraz Ca ira sp. z o.o. (lata 2008 i 2009), AKME-MEDIAN sp. z o.o. (rok 2008) i Polkomtel S.A. (rok 2009). Kierownik projektu i jego uczestnicy chcieliby niniejszym wyrazić gorące podziękowanie za to wsparcie, bez którego sprawny przebieg prac nie byłby możliwy.

${ }^{7}$ Por. dyskusja dotycząca tego problemu w: Koliński 2007b, s. 347-53.

${ }^{8}$ Misja pracowała w składzie: dr hab. Rafał Koliński, prof. UAM (kierownik, archeolog), dr Łukasz Rutkowski (archeolog), mgr Ksenia Kolińska (archeolog), mgr Jerzy Wierzbicki (archeolog, fotograf), mgr Jowan Kassim (archeolog), mgr Sa'ud Hussein (archeolog), mgr Dargham Muhammad (rysownik) oraz studenci IP UAM Iwona Barczyńska, Katarzyna Sztompka, Marika Święszkowska, Ewelina Wyszkowska, Adam Michatowski i Kajetan Polakowski.

${ }^{9}$ W skład misji wchodzili: dr hab. Rafał Koliński, prof. UAM (kierownik, archeolog), dr Łukasz Rutkowski (archeolog), mgr Ksenia Kolińska (archeolog), mgr Aleksandra Buchalik (archeolog), mgr Michał Krueger
} 
dwóch odkrytych wcześniej cmentarzysk z okresu ceramiki chaburskiej, a także badano południową część terenu zajętego przez budowle postakadyjskie, zidentyfikowane w 2008 r.

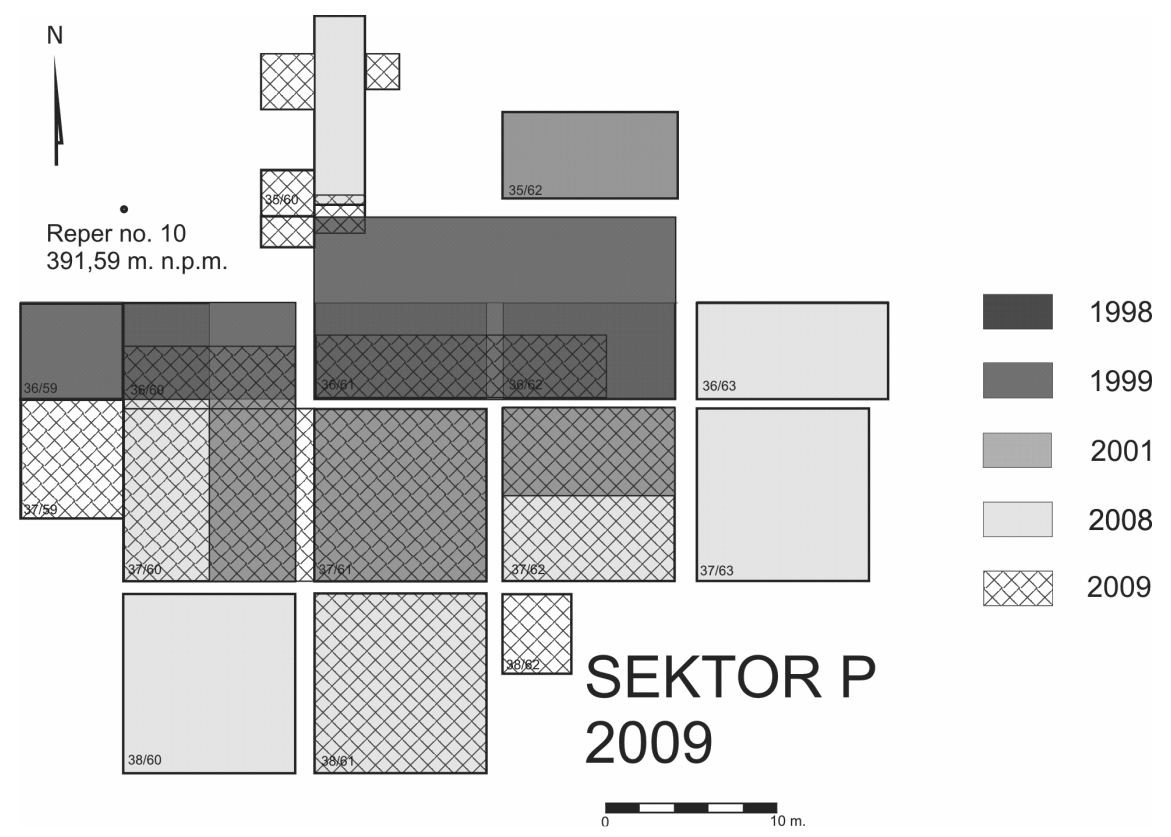

Ryc. 2. Przebieg prac w sektorze $P$ w latach 1998-2009 (rys. R. Koliński)

Fig. 2. Extent of work held in Sector P between 1998 and 2009 (drawn by R. Koliński)

\section{WYNIKI BADAŃ}

\section{Okres ceramiki chaburskiej (MBA II, ok. 1800-1700 p.n.e.)}

W trakcie badań prowadzonych w sektorze SR w latach 1998-2001 odsłonięto na powierzchni ok. $600 \mathrm{~m}^{2}$ dwa kompletne domy z okresu ceramiki chaburskiej i małe fragmenty należące do dwóch dalszych domów. W kwadratach otwartych w 2008 r., ulokowanych na południe i wschód od dotychczasowych wykopalisk (ryc. 2), napotkano dalsze pozostałości architektury mieszkalnej, będące kontynuacją wcześniej napotkanych budowli. Drugim ważnym odkryciem była identyfikacja i eksploracja cmentarzysk z tego samego okresu, leżących na zachód, północny zachód i na wschód od kompleksu

(archeolog), mgr Elżbieta Jezierska (biolog), Marcin Szabłowski (fotograf), mgr Jowan Kassim (archeolog), mgr Sa'ud Hussein (archeolog), mgr Fahad Hassan (archeolog), oraz studenci IP UAM: Iwona Barczyńska, Joanna Mardas, Agata Smilgin, Marika Święszkowska, Michał Lawer i Adam Szczęsny. 
domów mieszkalnych. W latach 1998-2001 odsłonięto w sumie cztery groby z tego okresu, w sezonie 2008 kolejnych dwanaście (trzy z nich nie były eksplorowane), zaś w sezonie 2009 zbadano dalszych piętnaście.

\section{Domy mieszkalne}

W trakcie dotychczasowych prac odsłonięto pozostałości pięciu domów mieszkalnych. Zbudowano je na opadającym dość łagodnie ku wschodowi zboczu tellu, przystosowując wcześniej ten teren pod zabudowę poprzez tarasowanie zbocza. W roku 2001 uchwycono obecność trzech tarasów, z których najszerszy, wschodni, zajęty był przez co najmniej trzy domy mieszkalne (I, II i IV), między którymi pozostawiono niezabudowaną przestrzeń. W 2008 r. zaobserwowano obecność czwartego, najniższego tarasu na wschodzie; na jego powierzchni wzniesiono Dom III (ryc. 3).

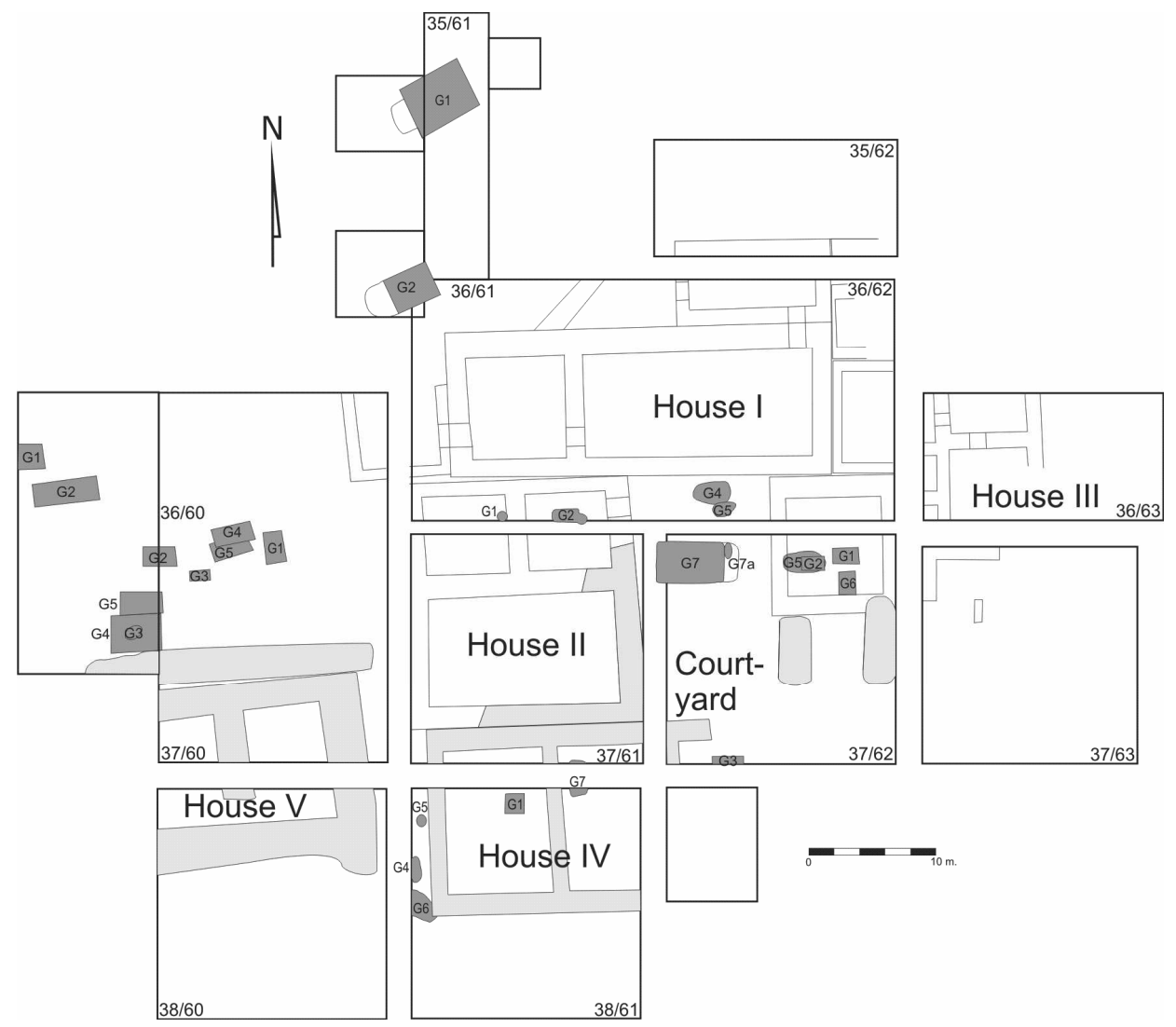

Ryc. 3. Pozostałości z okresu ceramiki chaburskiej odsłonięte w sekotrze P (rys. R. Koliński)

Fig. 3. Remnants of the Habur Ware period unearthed in Sector P (drawn by R. Koliński) 
Domy odkryte w północnej i wschodniej części sektora były dość dobrze zachowane, ze ścianami z cegły suszonej stojącymi do wysokości od 0,4 do 0,9 m. (Domy I i III). W części południowej ściany ceglane nie zachowały się, natomiast odkryto fundamenty wykonane z wilgotnej gliny, którą wypełniano głęboki wkop fundamentowy (Domy IV i V). Dom II również wybudowany został na takich fundamentach, z tym że w jego północnej części na fundamencie zachowała się ceglana nadbudowa. Badania prowadzone w 2008 i 2009 r. domu objęły Dom III, Dom IV i Dom V.

Dom III został odsłonięty fragmentarycznie w wykopie o wymiarach $3 \times 9$ m założonym w kwadracie 36/63 (ryc. 3). W jego obrębie odsłonięto kwadratowy dziedziniec o wymiarach ok. $3 \times 3 \mathrm{~m}$ (Locus 2), otwierający się prawdopodobnie na niezabudowaną przestrzeń na wschodzie. Wejście do domu, ulokowane w północnej ścianie dziedzińca, miało szerokość $0,9 \mathrm{~m}$ i po wewnętrznej stronie zaopatrzone było w kamienne jarzmo drzwiowe. Prowadziło ono do pokoju o szerokości ok. $3 \mathrm{~m}$ i nieznanej długości (Locus 1) (ryc. 4), zaopatrzonego w posadzkę z ubitej gliny. W jego zachodniej ścianie otwierały się kolejne drzwi, prowadzące ku zachodowi. W tej części domu, na zachód od dziedzińca i od Locus 1, odsłonięto fragmenty trzech dalszych pomieszczeń, z których tylko jedno, to, do którego prowadziły drzwi (Locus 4), było eksplorowane. Dom rozciągał się

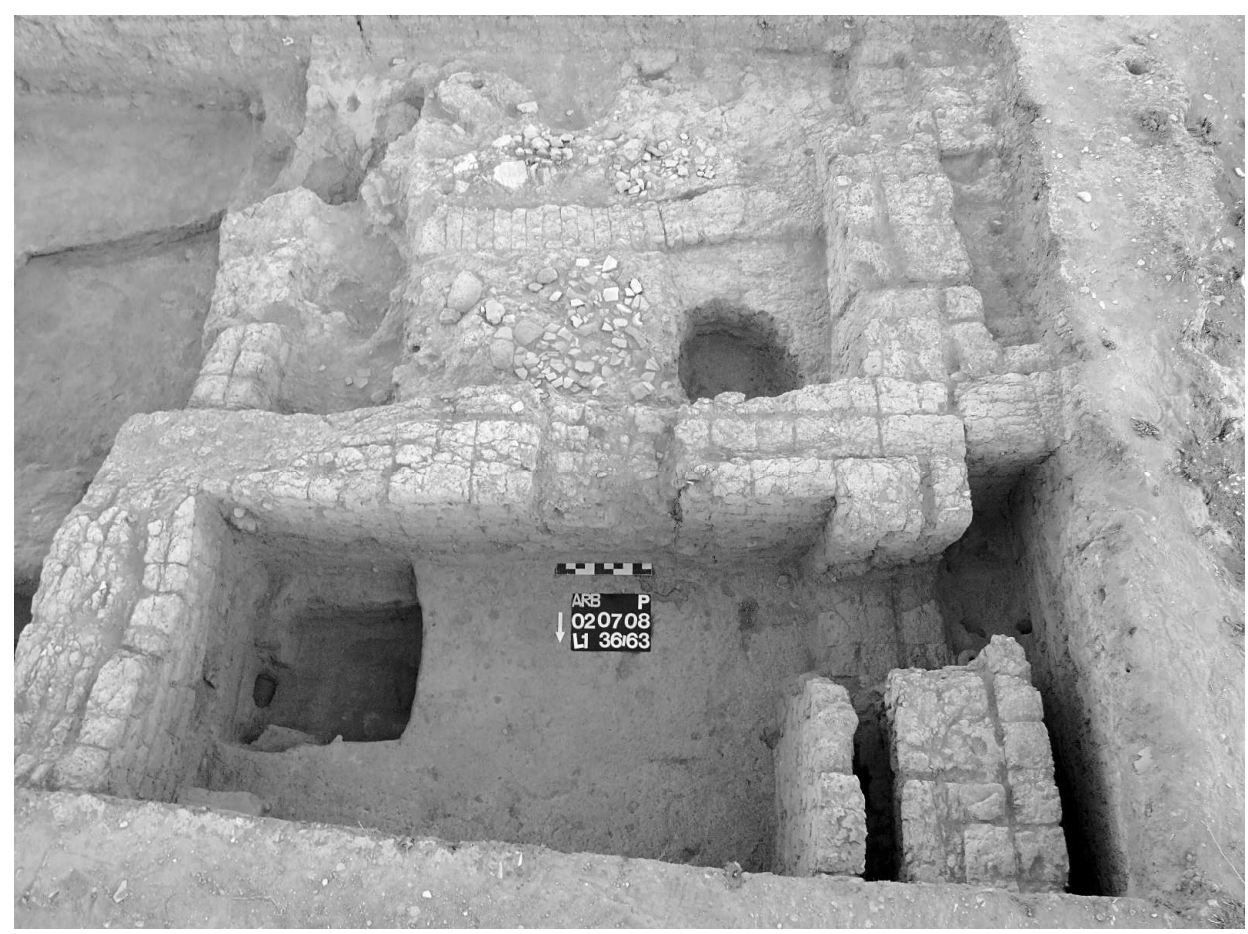

Ryc. 4. Część domu III z okresu ceramiki chaburskiej odsłonięta w kwadracie 36/63 (fot. J. Wierzbicki)

Fig. 4. Unearthed part of House III in sq. 36/63 (photo by J. Wierzbicki) 
dalej ku północy i zachodowi, gdzie jego pozostałości zostały odkryte w sondażach prowadzonych w kwadratach 36/62 (w 1998 r.) i 35/62 (w 2001 r.), ale jego plan nie może być jeszcze zrekonstruowany. Podobnie jak w domach eksplorowanych w sezonach 1998-2001 na posadzkach nie znaleziono żadnych znalezisk ruchomych, natomiast $\mathrm{z}$ wypełnisk pomieszczeń pochodzą liczne fragmenty ceramiki ( $\mathrm{w}$ tym malowanej ceramiki chaburskiej) oraz kilka fragmentarycznie zachowanych figurek zwierzęcych.

Dom IV miał ok. 6,3 m szerokości i co najmniej $11 \mathrm{~m}$ długości. Składał się najprawdopodobniej z trzech pomieszczeń o podobnej wielkości, ułożonych w amfiladzie; zarys północnego i środkowego zachowany jest w całości, natomiast wschodnie zostało niemal całkowicie zniszczone przez erozję. Prawdopodobne jest, że wschodnia ściana domu przebiegała po wschodniej krawędzi drugiego tarasu, dom zatem miałby ok. $16 \mathrm{~m}$ długości. Zarówno nadbudowa ścian, jak i poziomy podłogowe zostały całkowicie zniszczone przez erozję, więc nie dysponujemy żadnymi zabytkami wiążącymi się $\mathrm{z}$ użytkowaniem tego domu.

Dom $\mathbf{V}$, jako jedyny, wybudowany był na trzecim tarasie, wznoszącym się ok. 1,8 m nad poziomem tarasu drugiego. Podobnie jak w przypadku Domu IV, z budowli zachowały się tylko fundamenty z ubitej gliny. Dzięki ich przebiegowi można uznać, że Dom V rozplanowany był podobnie do Domu II: miał plan kwadratu o boku nieco ponad $10 \mathrm{~m}$. W jego obrębie znajdowały się trzy pomieszczenia: dwa mniejsze, prawie kwadratowe, na północy, i niemal nie zachowane, większe, prostokątne, na południu. Podobnie jak w wypadku Domu IV, nie ma żadnych znalezisk związanych z użytkowaniem omawianej budowli.

\section{Groby i cmentarzyska}

Siedem grobów odkrytych w pierwszych sezonach eksploracji warstw z okresu ceramiki chaburskiej nie tworzyło wyraźnych skupisk: trzy z nich znaleziono pod podłogami domów (zawierały szkielety niemowląt), resztę poza domami. Dopiero w wyniku kampanii przeprowadzonej w 2008 r. udało się zdefiniować trzy „cmentarzyska” (ryc. 3). Najmniejsze z nich, ulokowane na północny zachód od Domu I, tworzyły dwa rodzinne groby komorowe. Drugie, liczące 6 grobów skrzynkowych, ulokowano na otwartym terenie na trzecim tarasie, na zachód od Domu II i północ od Domu V. Do tego cmentarzyska należały także dwa groby naczyniowe. Trzecią koncentrację grobów odkryto na niezabudowanym dziedzińcu między Domami I, II i IV. Zlokalizowano tam jeden grób komorowy, 2 groby jamowe oraz 5 grobów naczyniowych. Do tego samego kompleksu może należeć pojedynczy grób skrzynkowy, który z braku darów grobowych trudno datować. Możliwe, że na południu sektora mamy do czynienia z kolejnym skupieniem grobów (częściowo pod Domem IV i na zachód od niego). Poza zniszczonym grobem komorowym odkryto tu kilka pochówków jamowych - były to pochówki wtórne bez wyposażenia, które mogą być przypisane okresowi chaburskiemu z racji pozycji stratygraficznej. 
Groby komorowe. Najciekawszą grupą grobowców są rodzinne groby komorowe. W sektorze P odsłonięto cztery takie konstrukcje (por. tab. 2), ale tylko trzy (G1/35/61, G2/35/61 i G7/37/62) zachowały się w stanie pozwalającym na analizę ${ }^{10}$.

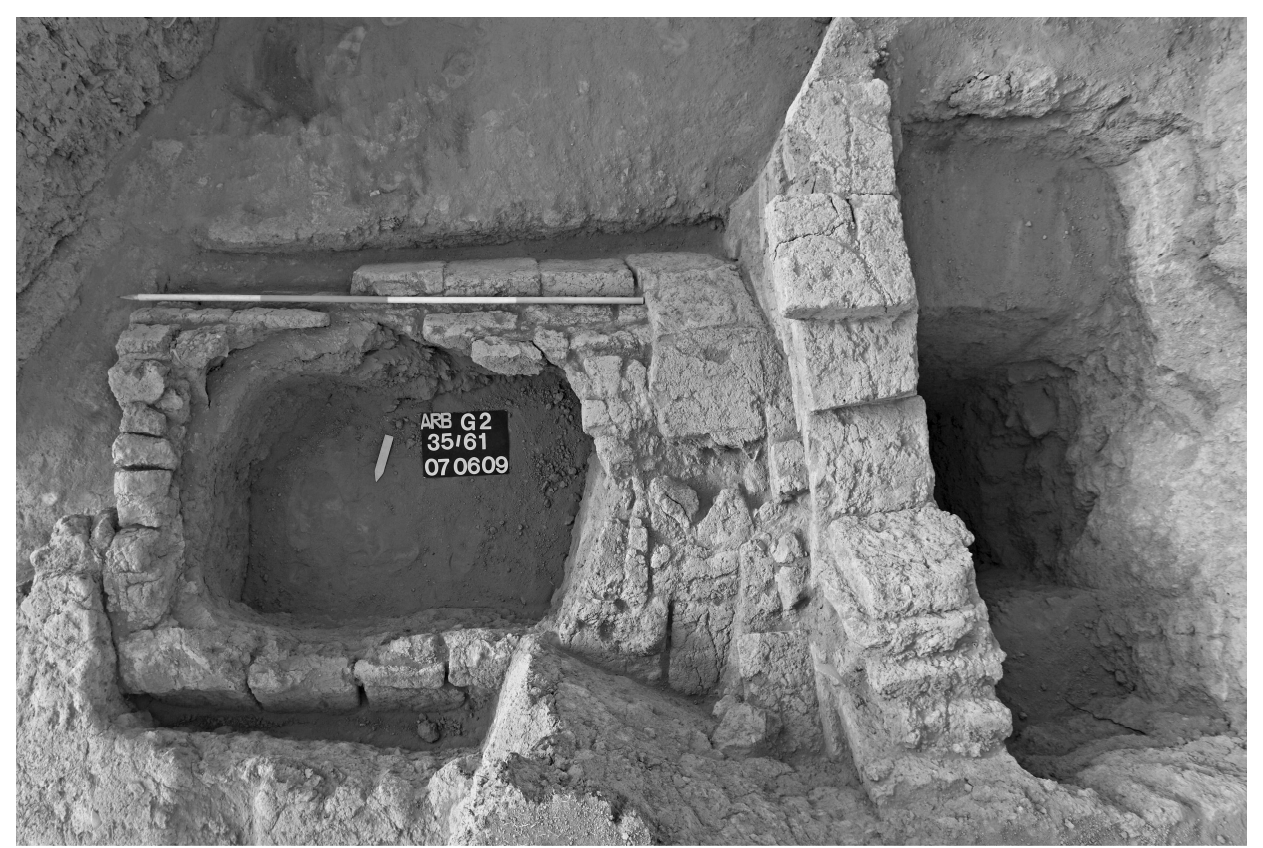

Ryc. 5. Grób komorowy G/35/61 z odsłoniętą komora grobowa i szybem (fot. M. Szabłowski)

Fig. 5. General view of G2/35/61 showing a grave chamber and a shaft (photo by M. Szabłowski)

Groby komorowe budowano na dnie jamy o wymiarach do $3 \mathrm{~m}$ długości i do $2 \mathrm{~m}$ szerokości, sięgającej ok. 1,7 do $2 \mathrm{~m}$ pod powierzchnię gruntu $\mathrm{z}$ okresu chaburskiego. $\mathrm{Na}$ jej dnie wznoszono komorę grobową $\mathrm{z}$ cegły mułowej o wymiarach wewnętrznych $2-1,8 \mathrm{~m}$ na $1,2-1,1 \mathrm{~m}$ zorientowaną na osi wschód - zachód. Komora od góry przekryta była sklepieniem beczkowym zamykającym się na wysokości od 1,2 do $1,35 \mathrm{~m}$ nad posadzką komory (ryc. 5). Jedno z łukowych „wejść” do komory zamurowywano, natomiast drugie, położone od strony szybu (w G1 i G2 na zachód od komory, w przypadku G7 na wschód), pozostawiano otwarte do czasu pogrzebu. Nad wejściem wznoszono ścianę oporową z cegły mułowej. Jej zadanie było dwojakie: zapobiegała osypywaniu się do szybu ziemi, którą przysypywano komorę po zakończeniu budowy grobu oraz oznaczała miejsce wejścia do grobu po całkowitym zasypaniu szybu. Po złożeniu zmarłego do grobu wejście do niego zamykano cegłami układanymi bez zaprawy a szyb zasypy-

\footnotetext{
${ }^{10}$ Obyczaje grzebalne na Tell Arbid w środkowym okresie epoki brązu zostały opracowane w rozprawie doktorskiej przez dr Zuzannę Wygnańską z IA UW (Wy gnańska 2006, 2012).
} 
wano. Groby komorowe służyły wielokrotnym pochówkom, więc co jakiś czas otwierano je ponownie w celu dołożenia nowego zmarłego. Usuwano wówczas ziemię z szybu i cegły zamykające komorę grobową. Szczątki wcześniejszego pochówku, wraz z należnymi mu darami, spychano w głąb komory, a na zwolnionym w ten sposób miejscu przy wejściu do komory układano kolejne ciało i wyposażenie grobowe.

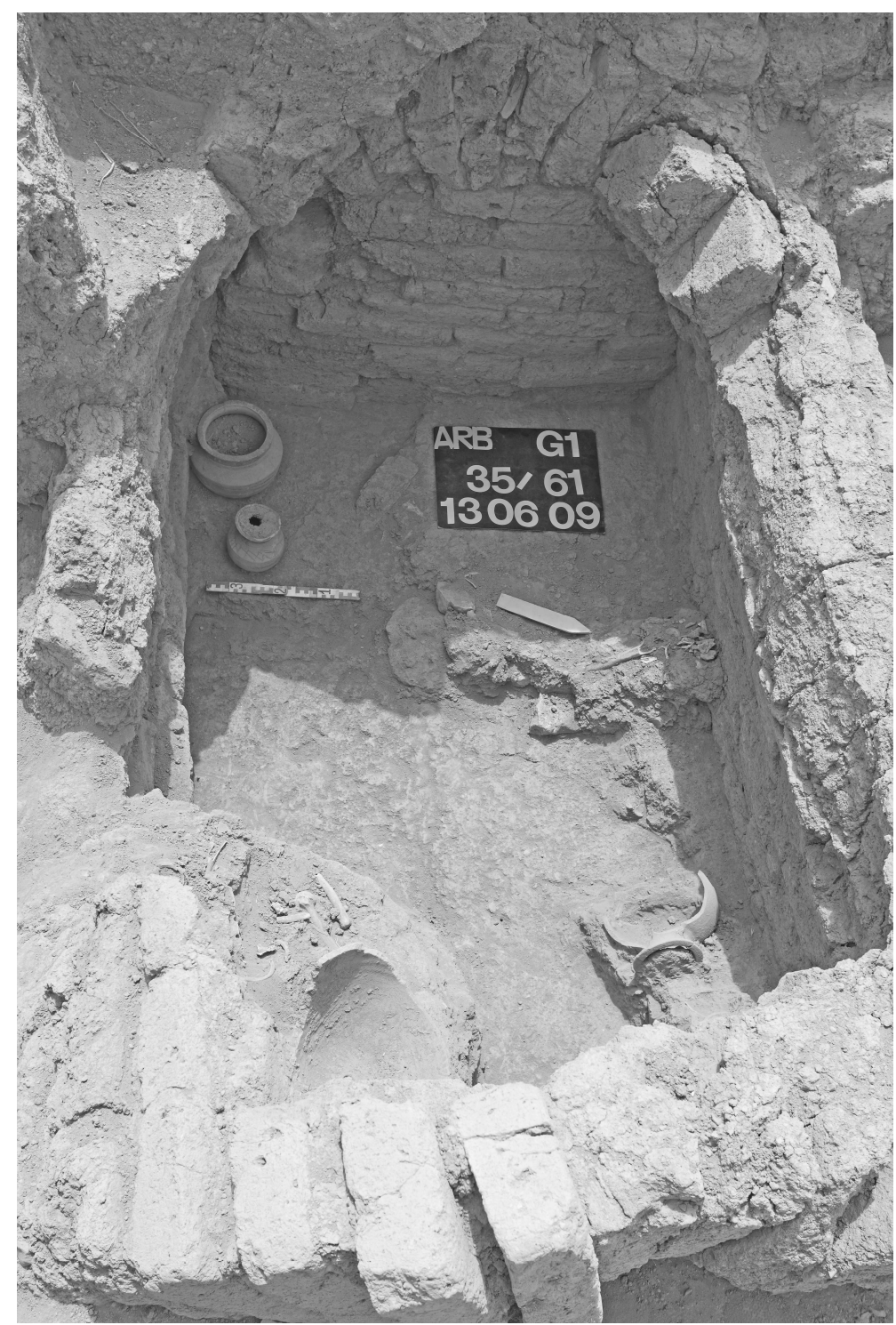

Ryc. 6. Wnętrze grobu komorowego G1/35/61 po eksploracji (fot. M. Szabłowski)

Fig. 6. Chamber of chamber grave G1/35/61 after exploration (photo by M. Szabłowski) 


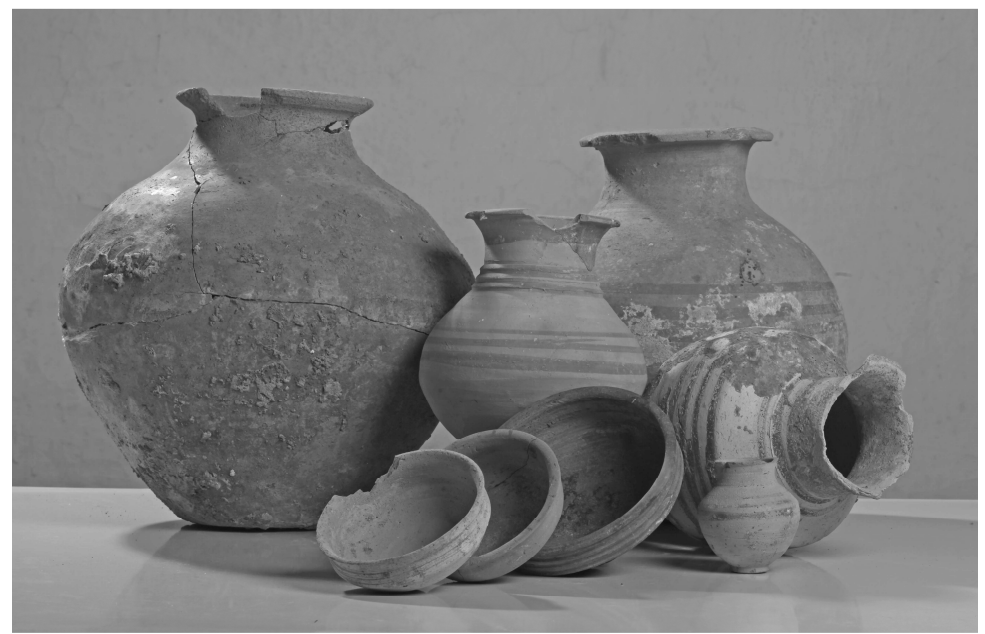

Ryc. 7. Naczynia ceramiki chaburskiej znalezione w grobie G7/37/62 (fot. M. Szabłowski) Fig. 7. Habur Ware pottery from grave G7/37/62 (photo by M. Szabłowski)

Groby G1 i G2 zostały najprawdopodobniej obrabowane w starożytności. W obu przypadkach pozostałości szybu rabunkowego prowadziły wprost do komory, niszcząc częściowo jej sklepienie. W G1 znaleziono szkielet młodej kobiety, którego dolna część leżała w porządku anatomicznym, górna rozrzucona była na dwóch poziomach w wypełnisku szybu rabunkowego; czaszki zaś brakowało (ryc. 6). W tym grobie znaleziono trzy naczynia ceramiczne i fragment (szpic) szpili z brązu. Grób G2 został całkowicie obrabowany: znaleziono tam tylko przemieszane kości dwóch osobników dorosłych ${ }^{11}$ oraz dwa małe paciorki z karneolu. Wiele niespodzianek przyniosła natomiast eksploracja grobu G7/37/62. Mimo że sklepienie komory częściowo uległo zniszczeniu, to grób ten nie został obrabowany. Znaleziono w nim szkielet kobiety w wieku ok. 35-40 lat ułożony w porządku anatomicznym przy wejściu do komory (pozycja kuczna na boku, głowa skierowana na zachód), któremu towarzyszyły dwa naczynia ceramiczne, trzy paciorki oraz szpila z brązu. Całą zachodnią część komory wypełniało rumowisko przemieszanych kości ludzkich (zidentyfikowano szczątki 5 osób dorosłych i siedmiorga dzieci) i zwierzęcych ${ }^{12}$, wśród których znajdowały się dalsze zabytki. W tej części odkryto sześć kolejnych naczyń ceramicznych (ryc. 7), szereg przedmiotów z brązu: topór (ryc. 8), trzy sztylety (lub groty włóczni), jedną bransoletę, dwie szpile, pęsetkę, oraz dwa okucia na laski i ponad 200 paciorków z kamieni półszlachetnych i masy gipsowej. Interesujące znaleziska pochodziły także z szybu grobu G7. W jego północnej części odkryto pochówek dziecięcy wyposażony w dwa naczynia (ryc. 9),

\footnotetext{
${ }^{11}$ Identyfikację szczątków kostnych przeprowadził dr hab. Arkadiusz Sołtysiak z IA UW (Sołtysiak, Koliński w druku).

${ }^{12}$ Szczątki zwierzęce przebadała dr Joanna Piątkowska-Małecka z IA UW.
} 


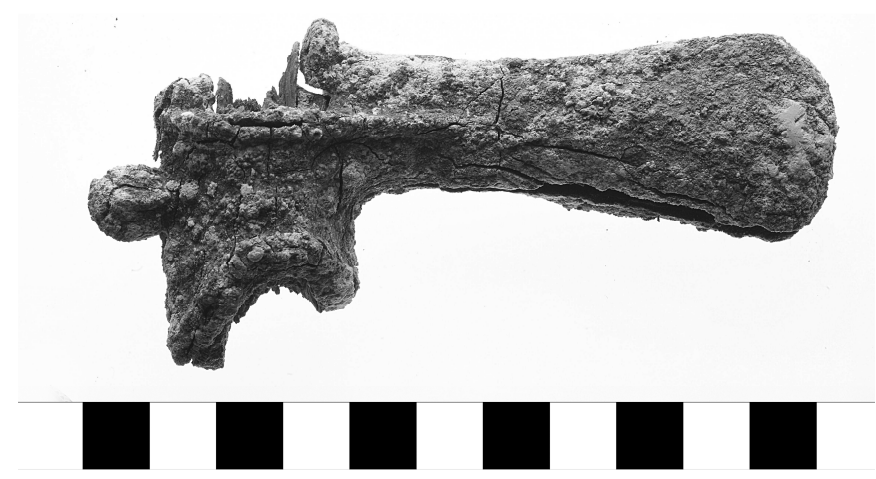

Ryc. 8. Toporek z brązu z widocznymi pozostałościami drzewca, grób G7/37/62 (fot. M. Szabłowski)

Fig. 8. Bronze axe with remains of a wooden shaft, grave G7/37/63 (photo by M. Szabłowski)

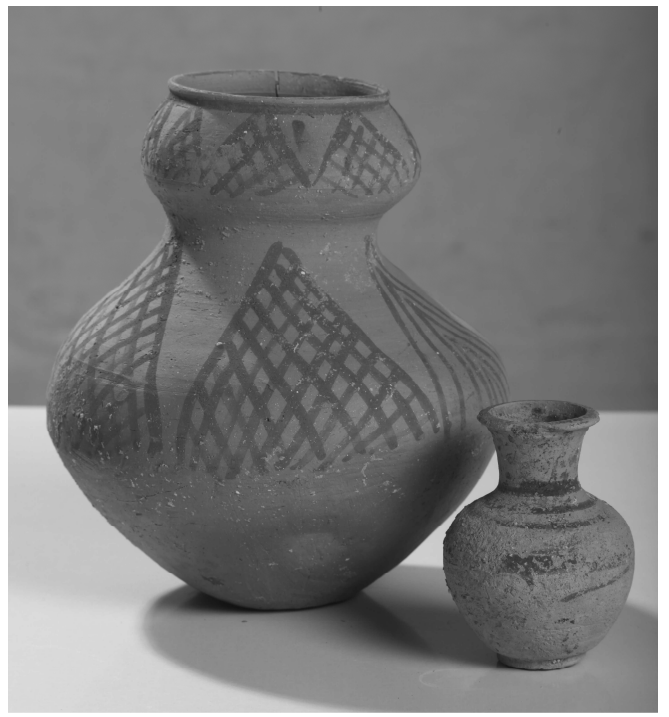

Ryc. 9. Naczynia z wczesnego okresu ceramiki chaburskiej z grobu G8/37/62 (fot. M. Szabłowski) Fig. 9. Early Habur Ware pottery from grave G8/37/62 (photo by M. Szabłowski)

dwie bransoletki z cyny (?) i paciorki z muszli (G8/37/62), a w zasypisku trzy dzbany zasobowe, kompletny szkielet $\mathrm{psa}^{13}$ oraz kości bydlęce, w tym kości szczęki i śródstopia $^{14}$. Wskazuje to, że ,przestrzeń rytualna” grobowca obejmowała nie tylko jego komorę,

${ }^{13}$ Podobne znalezisko z Arbidu por. Piątkowska-Małecka, Wygnańska 2006.

${ }^{14} \mathrm{~W}$ grobach z tego samego okresu z Tell Chagar Bazar, stanowiska leżącego ok. $10 \mathrm{~km}$ na zachód od Tell Arbid, zaobserwowano podobną regułę, jeśli chodzi o dystrybucję poszczególnych elementów szkieletów zwierzęcych, natomiast w 68 analizowanych grobach ani razu nie natrafiono na kości bydła (Cordy, Léon, Tunca 2009, s. 57, tab. 4, 5). 


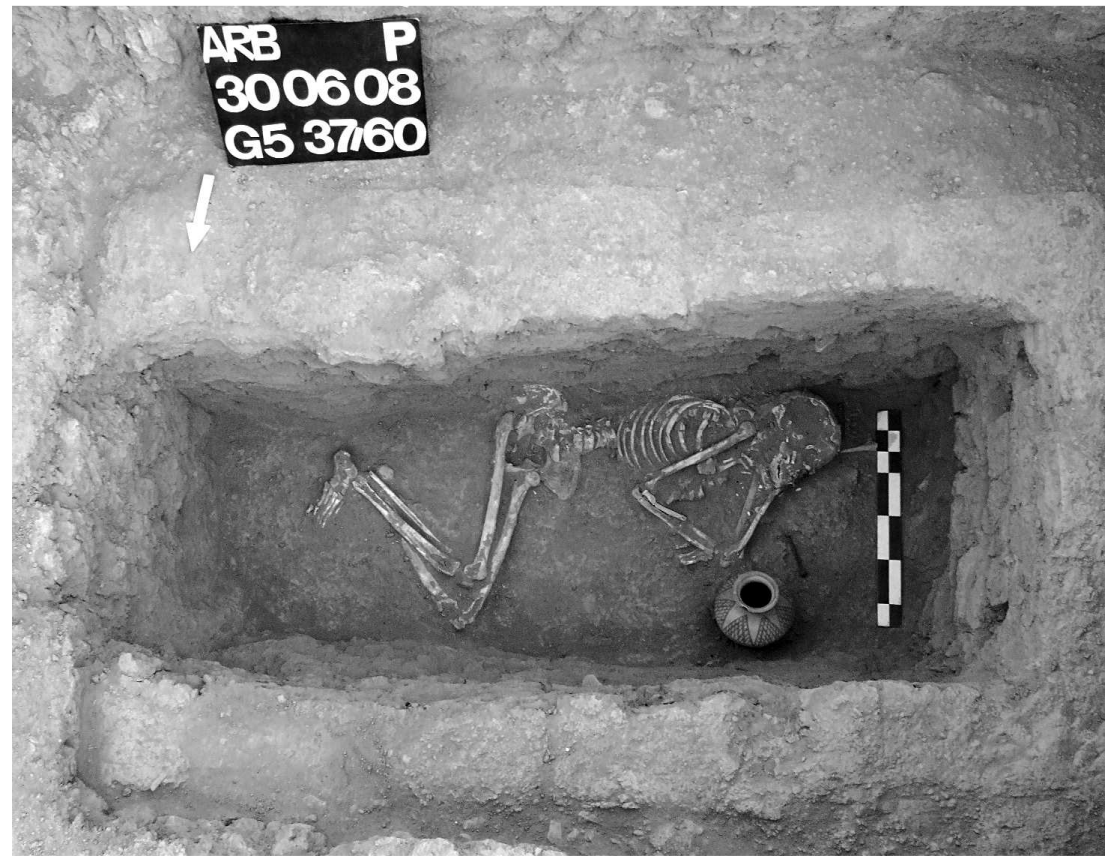

Ryc. 10. Grób skrzynkowy G5/37/60 z okresu ceramiki chaburskiej po eksploracji (fot. J. Wierzbicki) Fig. 10. Cist grave G5/37/60 of the Habur Ware period after cleaning (photo by J. Wierzbicki)

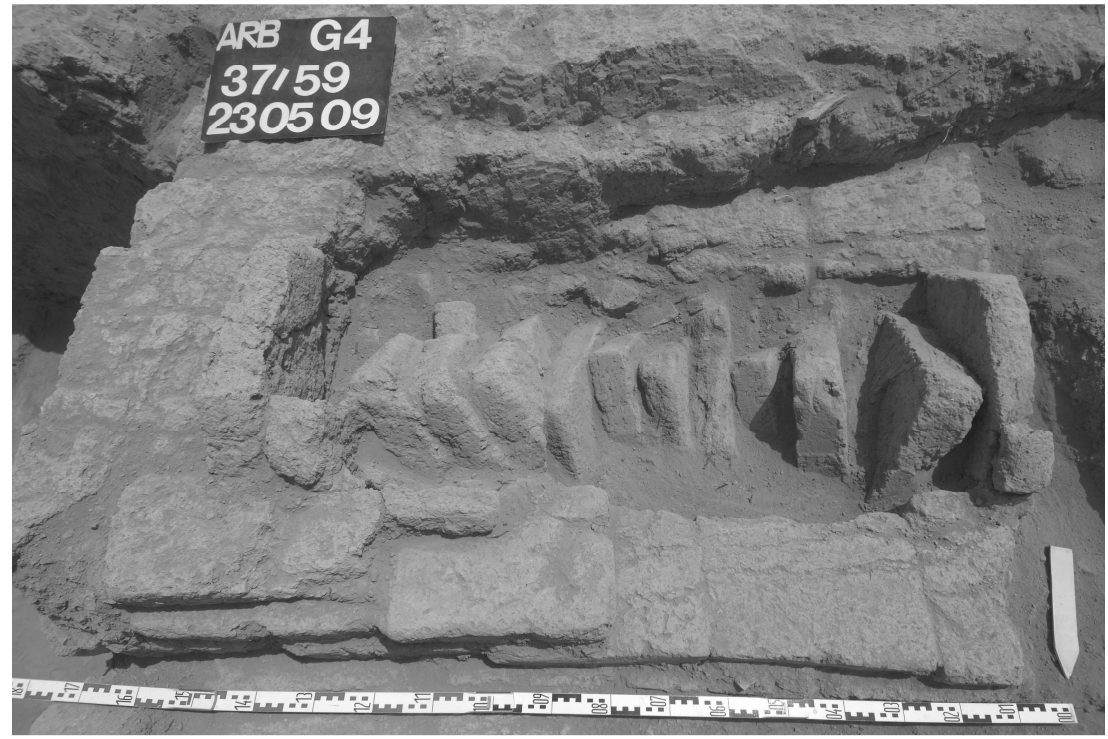

Ryc. 11. Grób skrzynkowy z przykryciem „w karo” - G4/37/59 (fot. R. Koliński)

Fig 11. Cist grave covered with bricks set „,in diamond” before exploration - G4/37-59 (photo by R. Koliński) 
Tabela 2. Groby chaburskie w sektorze SR/P $\mathrm{P}^{15}$. Przegląd typów i wyposażenia, orientacji oraz ułożenia ciał Table 2. Graves of the Khabur Ware Period in Sector SR/P. Review of typology and burial gifts, orientation, and body position

\begin{tabular}{|c|c|c|c|c|c|c|c|}
\hline Nr grobu & Sezon & Тур & $\begin{array}{l}\text { Orientacja, } \\
\text { ułożenie }\end{array}$ & $\begin{array}{c}\text { Liczba } \\
\text { i wiek zmarłych }\end{array}$ & Ceramika & Inne dary grobowe & $\begin{array}{c}\text { Kości } \\
\text { zwierzęce }\end{array}$ \\
\hline 1 & 2 & 3 & 4 & 5 & 6 & 7 & 8 \\
\hline G1/36/59 & 1998 & $\mathrm{~N}$ & $\mathrm{Z}-\mathrm{W}, 3$ & dziecko, 0,5 & 5 & $\begin{array}{l}4 \text { paciorki, obrączka z kości, } \\
\text { obrączka z metalu }\end{array}$ & - \\
\hline $\mathrm{G} 2 / 36 / 59$ & 1998 & $\mathrm{~S}$ & $\mathrm{Z}-\mathrm{W}, 2$ & dziecko, 6 & 2 & fragm. szpili z brązu, 5 paciorków & owca \\
\hline $\mathrm{G} 1 / 36 / 65^{*}$ & 1998 & $\mathrm{~S} ?$ & 4 & kobieta, $15-18$ & 1 & - & - \\
\hline $\mathrm{G} 2 / 36 / 65$ & 1998 & $\mathrm{~S}$ & 4 & dorosły & - & - & - \\
\hline $\mathrm{G} 1 / 36 / 62$ & 1999 & $\mathrm{~J}$ & PnW-PdZ, 3 & dziecko & - & - & - \\
\hline G1/35/64 & 2003 & $\mathrm{~S}$ & $\mathrm{~W}-\mathrm{Z}, 3 ?$ & dziecko, 7 & 6 & 1 bransoleta $\mathrm{z}$ brązu & tak \\
\hline $\begin{array}{l}\text { G1-G3/ } \\
36 / 64 \\
\end{array}$ & 2000 & $\mathrm{~J} ?$ & $?$ & dziecko i dorosły (?) & 4 & 6 paciorków & - \\
\hline $\begin{array}{l}\text { G2-G4/ } \\
36 / 64\end{array}$ & 2000 & $\mathrm{~K}$ & $?$ & $1+?$ & 6 & $\begin{array}{l}\text { grot włóczni z brązu, } 17 \text { pacior- } \\
\text { ków }\end{array}$ & owca \\
\hline G5/36/64 & 2003 & $\mathrm{~S}$ & W-Z, 3 & dziecko, 7 & 3 & 4 paciorki & - \\
\hline G6/36/64 & 2003 & $\mathrm{~N}$ & Z-W, 3 & dziecko 1,5 & 3 & - & - \\
\hline G7/36/64 & 2003 & $\mathrm{Sz}$ & W-Z, 3 & kobieta, 15-30 & 1 & $\begin{array}{l}\text { Szpila i figurka z brązu, } 3 \text { pacior- } \\
\text { ki, } 28 \text { krążków z muszli }\end{array}$ & - \\
\hline G8/36/64 & 2003 & $\mathrm{Sz}$ & $\mathrm{W}-\mathrm{Z}, 3$ & kobieta, 20-30 & 2 & $\begin{array}{l}\text { Szpila z brązu, } 2 \text { paciorki, } 19 \text { per- } \\
\text { forowanych muszelek }\end{array}$ & - \\
\hline G1/35/61 & 2008 & $\mathrm{~K}$ & $\mathrm{~W}-\mathrm{Z}, 2$ & dorosły $15-20$ & 3 & fragm. szpili z brązu & - \\
\hline G2/35/61 & 2008 & $\mathrm{~K}$ & W-Z, 4 & $\begin{array}{l}1 \text { mężczyzna, } \\
1 \text { dorosły }\end{array}$ & - & 2 paciorki & - \\
\hline G4/36/62 & 2009 & $\mathrm{~N}$ & PdZ-PnW, 3 & dorosły & 1 & - & - \\
\hline $\mathrm{G} 5 / 36 / 62$ & 2009 & $\mathrm{Sz}-\mathrm{N}$ & $\mathrm{W}-\mathrm{Z}, 3$ & dziecko, 3 & $12+1$ w szybie & 13 paciorków & - \\
\hline $\mathrm{G} 3 / 37 / 59$ & 2009 & $\mathrm{~N}$ & $\mathrm{Z}-\mathrm{W}, 3$ & dziecko, 0,75 & - & - & - \\
\hline $\mathrm{G} 1 / 37 / 60$ & 2001 & $\mathrm{~S}$ & $\mathrm{Pn}-\mathrm{Pd}, 2$ & mężczyzna & - & - & - \\
\hline $\mathrm{G} 2 / 37 / 60$ & 2008 & $\mathrm{~S}$ & $\mathrm{~W}-\mathrm{Z}, 2+4$ & 2 dorosłych & $3+1$ w szybie & $\begin{array}{l}\text { szpila, drut i naszywka z brązu, } \\
14 \text { paciorków }\end{array}$ & - \\
\hline $\mathrm{G} 3 / 37 / 60$ & 2008 & $\mathrm{~S}$ & 0 & - & - & - & - \\
\hline $\mathrm{G} 4 / 37 / 60$ & 2008 & $\mathrm{~S}$ & $\mathrm{~W}-\mathrm{Z}, 2$ & kobieta, $35-40$ & 1 & szpila z brązu & - \\
\hline G5/37/60 & 2008 & $\mathrm{~S}$ & $\mathrm{~W}-\mathrm{Z}, 2$ & kobieta, 30-35 & 1 & szpila $\mathrm{z}$ brązu & tak \\
\hline $\begin{array}{l}\mathrm{G} 6 / 37 / 60= \\
\mathrm{G} 4 / 37 / 59\end{array}$ & 2009 & $\mathrm{~S}$ & $\mathrm{~W}-\mathrm{Z}, 2$ & kobieta, $40-45$ & - & - & - \\
\hline $\begin{array}{l}\mathrm{G} 7 / 37 / 60= \\
\mathrm{G} 5 / 37 / 59\end{array}$ & 2009 & $\mathrm{~S}$ & $\mathrm{~W}-\mathrm{Z}, 2$ & kobieta & 1 & $\begin{array}{l}\text { szpila i pierścień z brązu, za- } \\
\text { wieszka, } 102 \text { paciorki }\end{array}$ & tak \\
\hline G1/37/61 & 2009 & $\mathrm{~N}$ & Pionowo, 0 & - & - & - & - \\
\hline $\mathrm{G} 2 / 37 / 61$ & 2009 & $\mathrm{Sz}-\mathrm{N}$ & PdW-PnZ, 3 & płód & 1 & - & - \\
\hline G1/37/62 & 2008 & $\mathrm{Sz}-\mathrm{N}$ & Pn-Pd, 3 & 4 dzieci $2,5-5$ & $5+2 w$ niszy & $\begin{array}{l}\text { pieczęć cylindryczna drut z brązu, } \\
\text { zawieszka z kamienia, } 4 \text { paciorki }\end{array}$ & - \\
\hline $\mathrm{G} 2 / 37 / 62$ & 2008 & $\mathrm{Sz}-\mathrm{N}$ & Pn-Pd, 3 & dziecko, 4 & $1+2 \mathrm{w}$ niszy & 1 paciorek & - \\
\hline $\mathrm{G} 4 / 37 / 62$ & 2008 & $\mathrm{~S}$ & $\mathrm{~W}-\mathrm{Z}, 2$ & dziecko, 2 & $?$ & $?$ & $?$ \\
\hline $\mathrm{G} 5 / 37 / 62$ & 2009 & Sz-N & W-Z, 3 & dziecko, 2 & $2+1 \mathrm{w}$ niszy & 4 paciorki & - \\
\hline G6/37/62 & 2009 & $\mathrm{Sz}-\mathrm{N}$ & $\mathrm{W}-\mathrm{Z}, 3$ & dziecko, 2 & - & 2 bransolety $\mathrm{z}$ brązu & - \\
\hline G7/37/62 & 2009 & $\mathrm{~K}$ & $\mathrm{~W}-\mathrm{Z}, 2+4$ & $\begin{array}{l}\text { kobieta } 35-40, \text { męż- } \\
\text { czyzna } 20-25,2 \text { ko- } \\
\text { biety, } 2 \text { mężczyzn, } \\
7 \text { dzieci (7-14, 5, } 4 \text {, } \\
3,0,75,0 \text { lat) }\end{array}$ & $8+3$ w szybie & $\begin{array}{l}\text { topór, } 3 \text { sztylety, bransoleta, pę- } \\
\text { setka, } 2 \text { okucia lasek z brązu, dysk } \\
\text { z kamienia, } 6 \text { niezident. przed- } \\
\text { miotów z metalu, } 350 \text { paciorków }\end{array}$ & tak \\
\hline
\end{tabular}

${ }^{15}$ Informacje o grobach z sezonów 1998, 2000, 2001 i 2003 za: Wygnańska 2006. 
cd. tab. 2

\begin{tabular}{|c|c|c|c|c|c|c|c|}
\hline 1 & 2 & 3 & 4 & 5 & 6 & 7 & 8 \\
\hline $\mathrm{G} 8 / 37 / 62^{* *}$ & 2009 & $\mathrm{~J}(?)$ & $\mathrm{N}-\mathrm{S}, 4 ?$ & dziecko, 0,75 & 2 & $\begin{array}{l}2 \text { bransolety } \mathrm{z} \text { cyny, paciorki } \\
\mathrm{z} \text { muszli }\end{array}$ & - \\
\hline $\mathrm{G} 1 / 38 / 61$ & 2008 & K & Pn-Pd, ? & $\begin{array}{l}2 \text { dorosłych, } \\
\text { dziecko, 3-7 }\end{array}$ & - & fragm. moździerza z bazaltu & - \\
\hline G5/38/61 & 2009 & $\mathrm{~J}$ & 4 & kobieta, $25-35$ & - & - & - \\
\hline G6/38/61 & 2009 & $\mathrm{~J}$ & 4 & 2 dzieci & - & - & - \\
\hline $\mathrm{G} 7 / 38 / 61$ & 2009 & $\mathrm{~J}$ & $?$ & dorosłych, 15 & $?$ & $?$ & $?$ \\
\hline
\end{tabular}

Typy: J - jamowy, K - komorowy, N - naczyniowy, S - skrzynkowy, Sz-N - szybowy - naczyniowy. Pozycja szkieletu: 0 - nie eksplorowany, 1 - wyprostowana, 2 - na boku, ugięte nogi, 3 - embrionalna, 4 - bez zachowania porządku anatomicznego Typology: J - pit, K - chamber, N - pot, Sz-N shaft + pot; Z - west, Pn - north, W - east, Pd - south. Position of skeleton: 0 - not explored, 1 - stretched, 2 - on side, with bend legs, 3 - constricted, 4 - bones out of anatomical order

* Grób został zbadany tylko częściowo.

** W szybie grobu $\mathrm{G} 7 / 37 / 62$.

ale także prowadzący do niego szyb, do którego trafiały m.in. pozostałości po ofiarach zwierzęcych wkładanych do grobu i po uczcie pogrzebowej.

Wszystkie znalezione dotychczas $\mathrm{w}$ Sektorze $\mathrm{P}$ groby skrzynkowe pochodzą $\mathrm{z}$ „,cmentarza zachodniego”. Podobnie jak groby komorowe, były one konstruowane z cegły mułowej na dnie głębokiej jamy zorientowanej na linii wschód - zachód. Ponieważ jednak groby skrzynkowe służyły jako miejsce spoczynku jednego zmarłego to ich komora była mniejsza (do 1,8 m długości i do $0,7 \mathrm{~m}$ szerokości), otoczona cegłami tylko $\mathrm{z}$ trzech stron i nie były one wyposażane w szyb prowadzący do grobu (ryc. 10) ${ }^{16}$. W grobach skrzynkowych znaleziono głównie szkielety osób dorosłych, ułożonych w pozycji kucznej, z głowa skierowaną albo na wschód albo na zachód (ryc. 10). Dary ograniczały się najczęściej do jednego naczynia ceramicznego, szpili z brązu oraz, niekiedy, pewnej liczby paciorków (por. tab. 2). Ciało zmarłego, po złożeniu do grobu, przysypywano cienką warstwą ziemi i przykrywano kwadratowymi cegłami mułowymi ustawionymi na sztorc (stąd określenie ,groby skrzynkowe w karo”) (ryc. 11). Groby tego typu znane są z innych sektorów na Tell Arbid, ale nie wystąpiły na współczesnych $\mathrm{mu}$ stanowiskach $\mathrm{z}$ regionu chaburskiego ${ }^{17}$.

Groby naczyniowe wystąpiły w dwóch odmianach: gdy naczynie ceramiczne użyte jako pojemnik na ciało ułożone jest pionowo na dnie jamy wykopanej w ziemi i gdy naczynie umieszczone jest w niszy wydrążonej w ścianie prostokątnego szybu. W sektorze P odkryto groby obu rodzajów, ale te drugie były częstsze: należy do nich większość grobów odkrytych na cmentarzu wschodnim (G1-2/37/62, G5-6/37/62 oraz G5/36/62). $\mathrm{W}$ ich przypadku, jako pojemnika na ciało dziecka w wieku od 2 do 5 lat używano duże-

\footnotetext{
${ }^{16}$ Wyjątkowy pod tym względem był grób G2/37/60, w którym znaleziono kości dwóch dorosłych osobników. Jest to też jedyny grób skrzynkowy, który zaopatrzony został w szyb prowadzący do zachodniego wejścia do komory; w szybie znaleziono jeden dzban. Obecność szybu trzeba wiązać z dokonaniem kolejnego pochówku.

${ }^{17}$ Wygnańska 2006.
} 


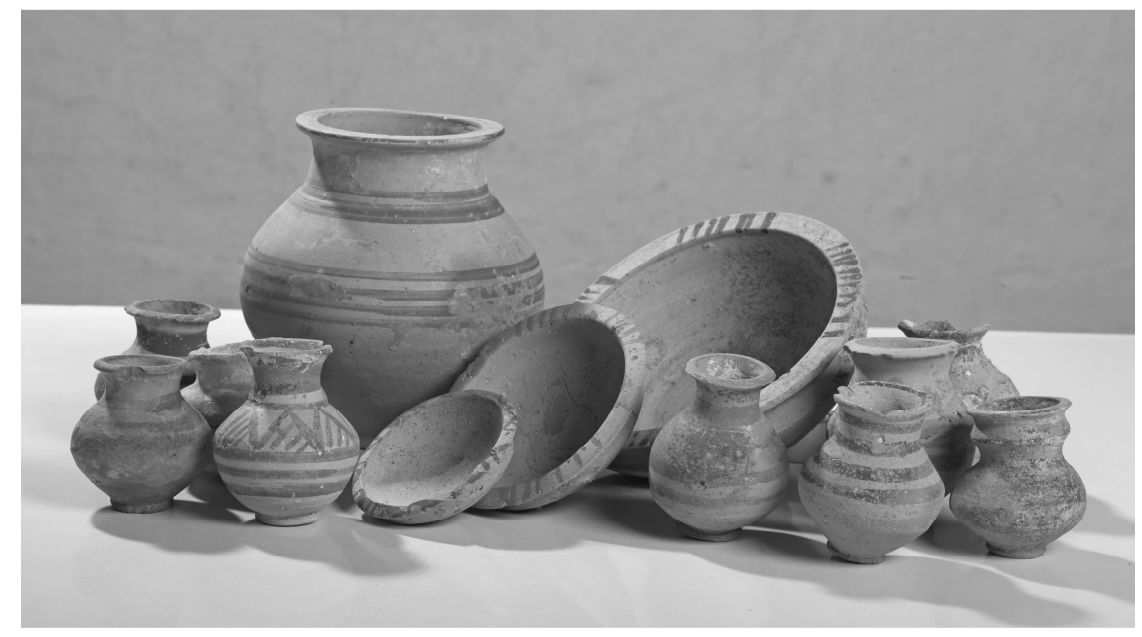

Ryc. 12. Naczynia ceramiki chaburskiej znalezione w grobie G5/36/62 (fot. M. Szabłowski) Fig. 12. Habur Ware pottery from grave G5/36/62 (photo by M. Szabłowski)

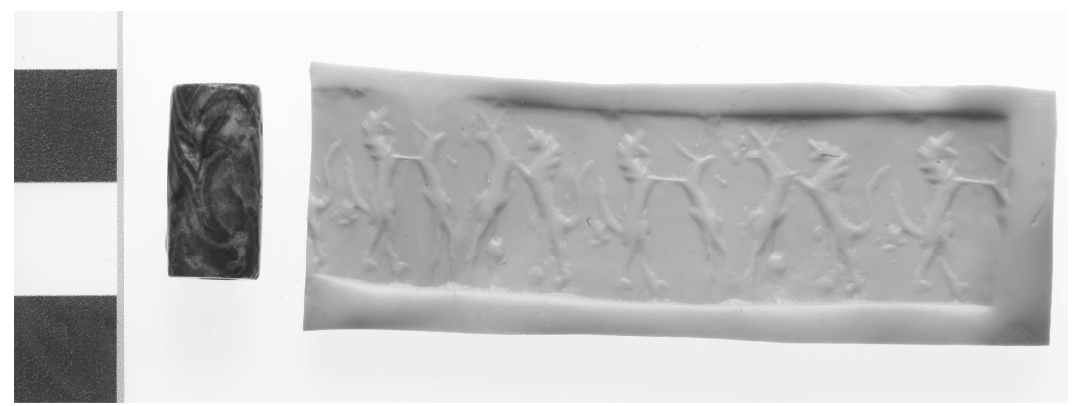

Ryc. 13. Wczesnodynastyczna pieczęć cylindryczna znaleziona w grobie G1/37/62 (fot. M. Szabłowski) Fig. 13. An ED III cylinder seal from Habur period grave G1/37/62 (photo by M. Szabłowski)

go dzbana, często z utrąconym dnem. Naczynie układano na boku, niekiedy kierując jego otwór ku ściance niszy. W takim przypadku niszę niekiedy zamykano kilkoma cegłami. Jeśli otwór naczynia skierowany był ku szybowi, zawsze zamykano go cegłą. Nie zaobserwowano prawidłowości w orientacji naczynia i kierunku ułożenia otworu ani preferencji w lokalizacji niszy w stosunku do szybu. Do naczynia prócz ciała wkładano co najmniej jedno miniaturowe naczynie (ale w najbogatszym grobie G5/36/62 było ich aż 13 - ryc. 12); jeśli w skład zastawy wchodził większy dzbanek, to ustawiano go osobno, albo w szybie lub w niszy. W jednym z grobów (G6/37/62) nie znaleziono ceramiki, natomiast na kościach przedramion zachowały się dwie bransolety z brązu. Wyjątkowy okazał się grób G1/37/62, ponieważ złożono w nim ciała aż czworga dzieci w wieku między 2,5 a 5 lat, a jednym z darów była pieczęć cylindryczna z poł. III tysiąclecia 
p.n.e. wykorzystana jako amulet (ryc. 13). Groby należące do pierwszej grupy z zasady wykorzystywały naczynia ceramiki kuchennej jako pojemnik na ciało i nie zawierały żadnych darów grobowych. Chowano w nich dzieci poniżej 1 roku życia lub płody.

\section{Okres handlu staroasyryjskiego (MB I, ok. 1950-1800 p.n.e.)}

Staroasyryjski szlak handlowy łączący Aszur z centrum Anatolii z pewnością przebiegał przez równinny teren Trójkąta Chaburskiego, jednak do 2006 r. ceramika $\mathrm{z}$ tego okresu była zupełnie nieznana współczesnej nauce ${ }^{18}$. W trakcie prac w Sektorze P udało się po raz pierwszy pozyskać ceramikę bardzo podobną do tej z Tell Barri, z dobrze zdefiniowanych kontekstów archeologicznych, przede wszystkim obszernych jam wypełnionych popiołami, które od góry zapieczętowane są fundamentami budynków chaburskich i które przecinają mury struktur postakadyjskich (jedna z tych jam była eksplorowana w 2009 r., druga w 2010). Ponadto w południowej części kwadratu 37/62 odsłonięto fragment muru z cegły suszonej, z piecem chlebowym i częściowo wkopanym w ziemię dzbanem, w którym znaleziono czarkę o dekoracji charakterystycznej dla tego okresu. Są to pierwsze pozostałości strukturalne z tego okresu na Tell Arbid. Opierając się na ich obecności, a także pewnej ilości ceramiki z okresu MBA I znalezionej na Cytadeli i w zachodniej części głównego tellu, możemy poważnie potraktować propozycję identyfikacji Tell Arbid z osadą o nazwie Amaz, która była z jedną ze stacji na szlaku karawanowym.

\section{Okres postakadyjski (EJ V, ok. 2150-2000 p.n.e.)}

Dwa sezony badań pozwoliły odsłonić obszerną część kompleksu budowli z okresu postakadyjskiego, obejmującego ok. $350 \mathrm{~m}^{2}$ powierzchni (ryc. 14). Łatwo można wydzielić dwa elementy zabudowy: „Main Building”, budynek o grubych ścianach, który z niewielkimi zmianami użytkowany był przez cały okres trwania kompleksu, oraz dostawiane do niego lub wznoszone obok mniejsze budowle. Ich żywot był krótszy niż okres użytkowania „Main Building”, toteż z zasady napotykamy na sekwencję dwóch, a w niektórych miejscach trzech różnych konstrukcji leżących jedna nad drugą. Wszystkie te konstrukcje określane są terminem Extensions. Zachodnią granicę zabudowy postakadyjskiej stanowiło zabezpieczone murami oporowymi zbocze tellu, wznoszące się ku leżącej w tym kierunku kulminacji wzgórza. Konieczność ustabilizowania zbocza wynikała z faktu, że aby powiększyć teren do wykorzystania pod zabudowę zniwelowano część stoku (miejscami wkopując się w niego do głębokości ponad 2,5 m). Na południu

\footnotetext{
${ }^{18}$ Włoscy archeolodzy pracujący na Tell Barri $(20 \mathrm{~km}$ na pd.-wsch. od Tell Arbid) zaprezentowali po raz pierwszy ceramikę z tego okresu podczas 6. ICAANE w Madrycie, w 2006 r., por. Baccelli, Manuelli 2008 .
} 


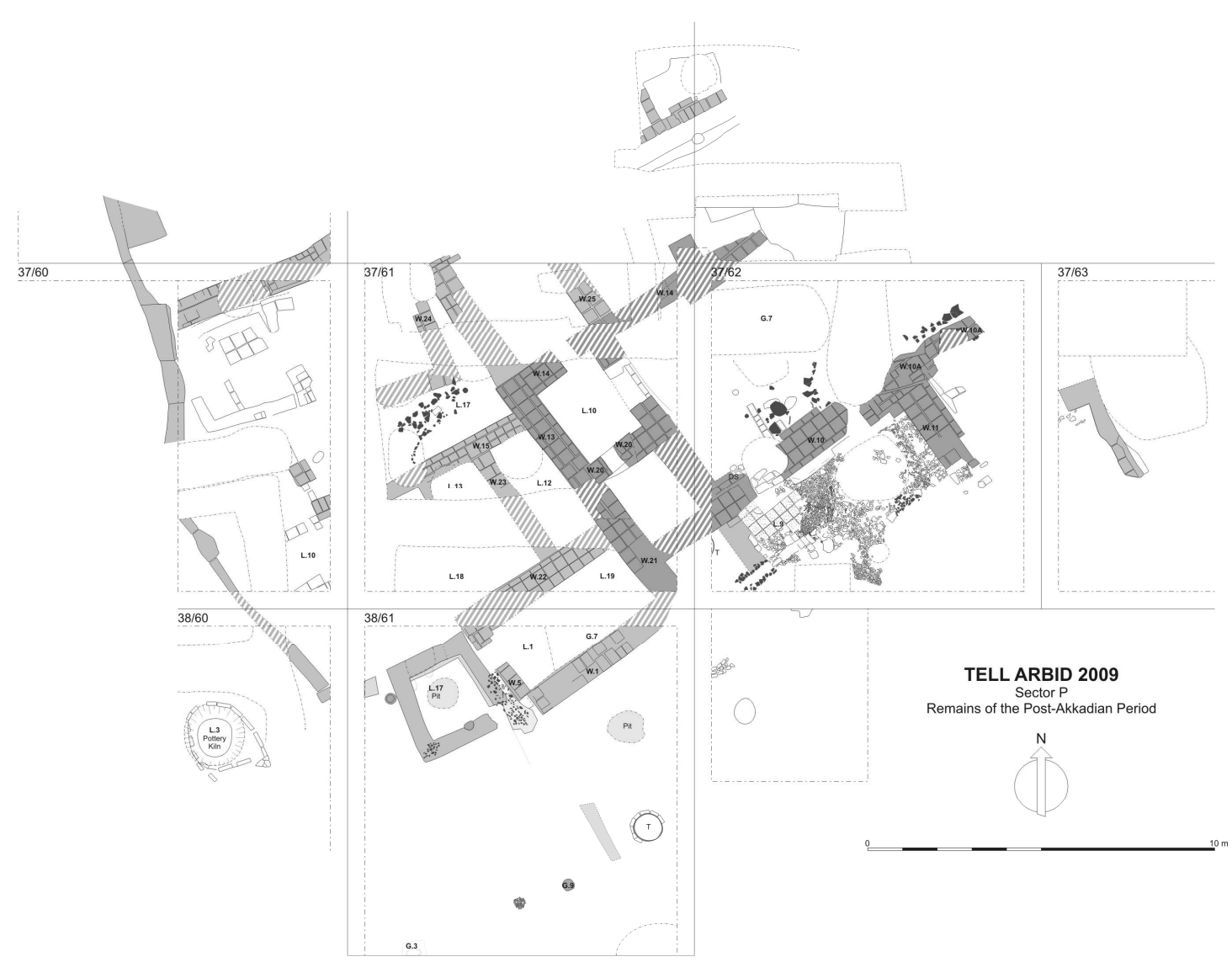

Ryc. 14. Pozostałości z okresu postakadyjskiego odsłonięte w sekotrze P (rys. M. Momot)

Fig. 14. Remnants of the post-Akkadian period structures unearthed in Sector P (drawn by M. Momot)

granicę zabudowy wyznacza otwarta przestrzeń użytkowa, na której zlokalizowane zostały instalacje o charakterze gospodarczym; $z$ tego rejonu pochodzą wszystkie znalezione dotąd groby postakadyjskie. Na wschodzie zabudowa została w dużej części zniszczona w wyniku tarasowania stoku przeprowadzonego w okresie chaburskim (por. wyżej). Na północy pozostałości z epoki postakadyjskiej kryją się pod domami z okresu chaburskiego i nie zostały jeszcze w pełni rozpoznane.

„Main Building”. Najważniejsza struktura kresu postakadyjskiego odnaleziona w Sektorze P to budynek o wymiarach w rzucie ok. $11 \times 15 \mathrm{~m}$. Jego pełne pierwotne wymiary mogły być jednak większe, bo nie udało się jak dotąd zlokalizować ani jego południowej, ani wschodniej granicy. W południowo-zachodniej części zlokalizowany był obszerny, brukowany dziedziniec (Locus 9) na 5,75 m długi i na co najmniej 4,2 $\mathrm{m}$ szeroki (ryc. 15). Jego powierzchnia w większej części wyłożona była drobnymi otocza- 


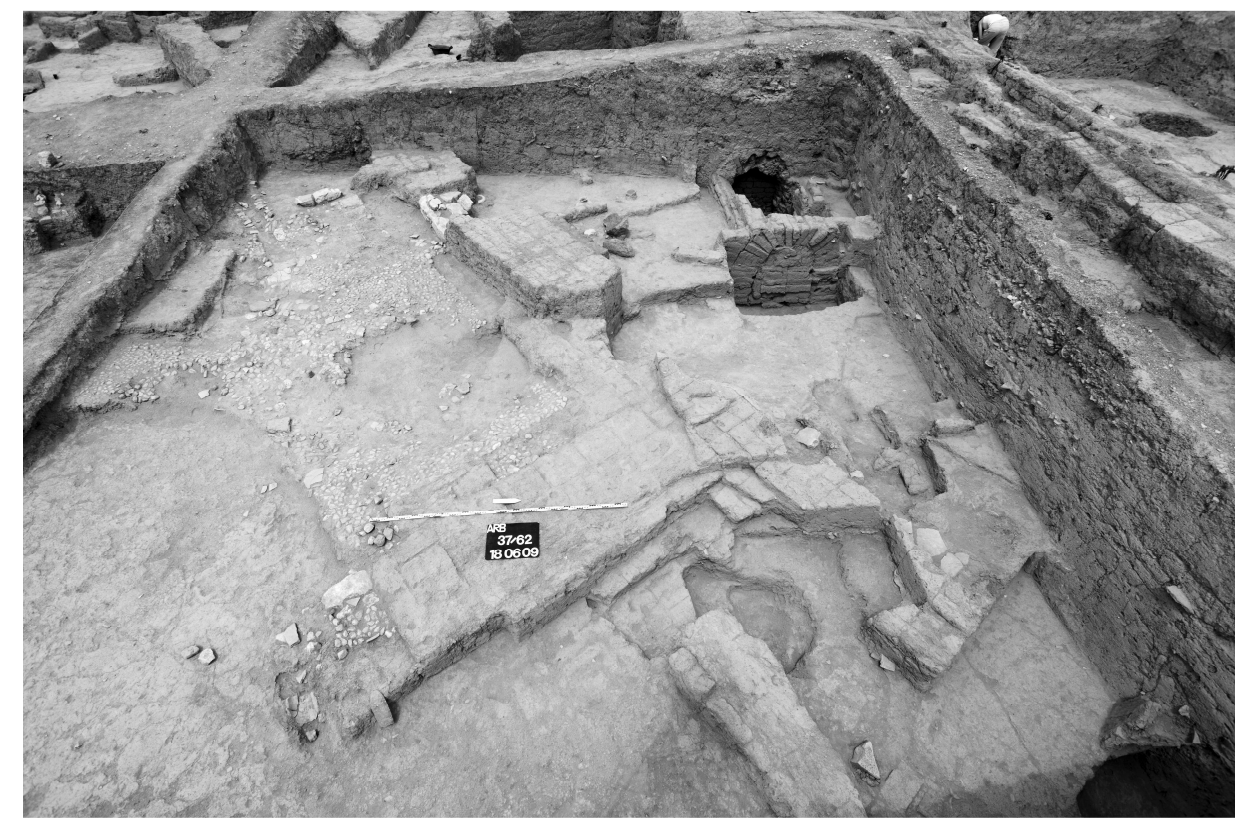

Ryc. 15. Kwadrat 37/62: pozostałości „Main Building” z okresu postakadyjskiego i wkopany w jego podłogę chaburski grób G7/37/62 (fot. M. Szabłowski)

Fig. 15. Post-Akkadian „Main Building” and MBA period chamber grave G7/37/62 cutting into its floor in sq. $37 / 62$ (photo by M. Szabłowski)

kami kamiennym (o długości do 0,06 m), tylko w północno-zachodnim narożniku, gdzie usytuowane było główne wejście do budynku, powierzchnię pokryto kilkunastoma wypalonymi cegłami o długości boków $0,32 \mathrm{~m}$. Od zachodu przylegała do dziedzińca niebrukowana przestrzeń, gdzie zlokalizowano piec chlebowy. Od północy i wschodu granicę dziedzińca wyznaczały mury „Main Building”, natomiast nie udało się dotąd znaleźć krańca południowego, nie wiadomo zatem czy i od tej strony był on otoczony murem. Ściany „Main Building” wzniesiono z kwadratowych cegieł mułowych o długości boku $0,36 \mathrm{~m}$ i prostokątnych cegieł stanowiących połowę pełnej cegły. Mury zewnętrzne miały $2 \frac{1}{2}$ cegły szerokości (ok. $1 \mathrm{~m}$ ), a mury działowe były szerokie na 2 cegły (ok. $0,8 \mathrm{~m}$ ). Wszystkie ściany pokryto grubą na kilka centymetrów warstwą czerwonawej gliny, stanowiącej tynk; znacznie lepiej zachowała się ona na ścianach wewnątrz budynku. Podłogi w pomieszczeniach wykonane zostały z cienkiej warstwy gliny.

Do tej pory odsłonięto $\mathrm{w}$ całości trzy pomieszczenia zlokalizowane $\mathrm{w}$ zachodniej części budowli. Główne wejście, szerokie na $0,9 \mathrm{~m}$, zaopatrzone zostało w próg z kilku dużych kamieni pokrytych glinianym tynkiem. Wewnątrz pomieszczenia, po lewej stronie od wejścia umieszczono duże kamienne jarzmo drzwiowe, co wskazuje, że drzwi osadzono po wewnętrznej stronie otworu i że otwierały się one do wewnątrz. Za drzwiami znajdowało się główne pomieszczenie budowli: niemal kwadratowy pokój 
o długości ok. 5,75 m i szerokości $5 \mathrm{~m}$ (Locus 13). Jego wschodnia ściana została, niestety, niemal całkowicie zniszczona przez późniejszą jamę, stąd trudności z odtworzeniem oryginalnych wymiarów. Południowa ściana była podparta płaską przyporą o szerokości ok. 1,4 m; podobna przypora znajdowała się na ścianie północnej. Nie udało się ustalić, czy podobne przypory istniały na pozostałych ścianach. Większa część posadzki pomieszczenia została zniszczona przez późniejsze jamy, tylko w południowo-zachodniej części udało się odsłonić oryginalną podłogę. Na niej znaleziono dwa kompletne naczynia, moździerz i żarna z bazaltu oraz dużą liczbę fragmentów ceramiki (ryc. 16).

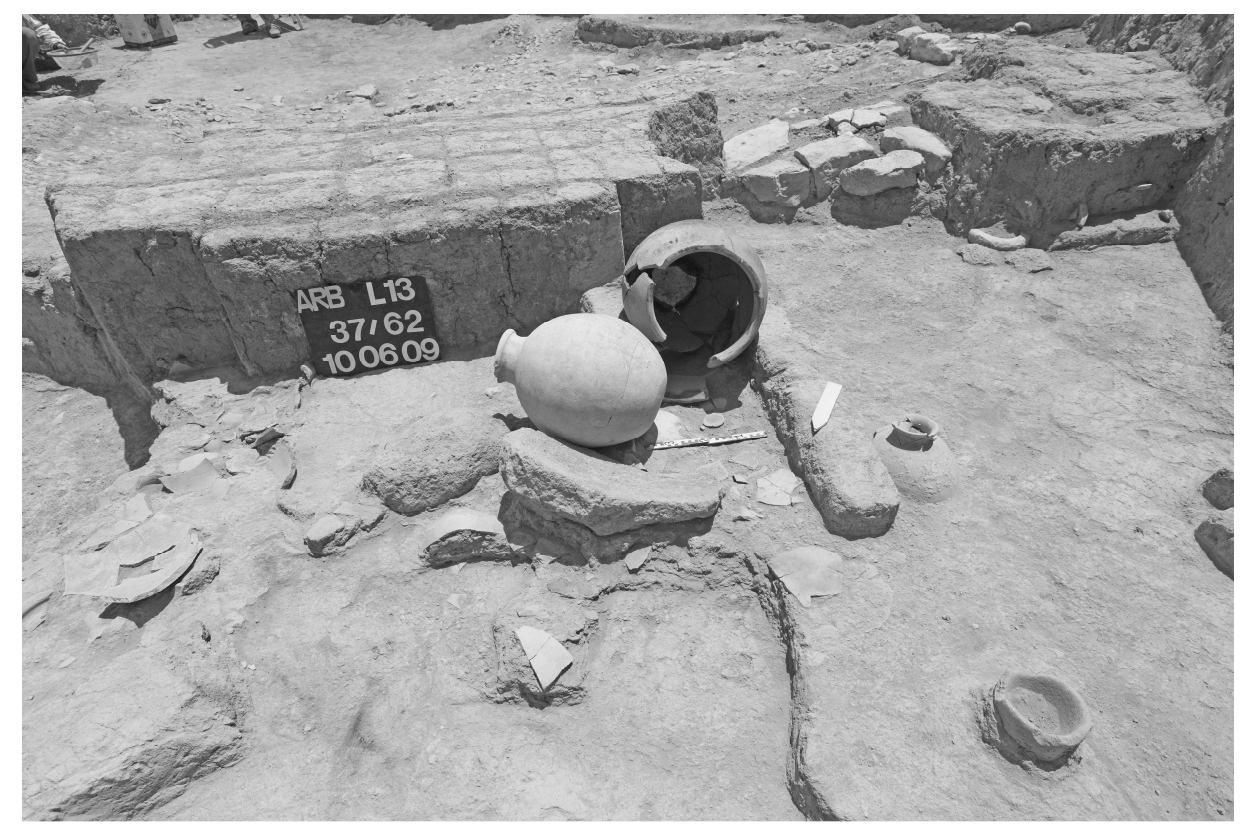

Ryc. 16. Postakadyjska ceramika i bazaltowe rozcieracze na podłodze Locus 13 w „Main Building” (fot. M. Szabłowski)

Fig. 16. Pottery vessels and a basalt quern on the floor of Locus 13 of „Main Building” (photo by M. Szabłowski)

W zachodniej ścianie Locus 13 znajdowały się drzwi prowadzące do małego pomieszczenia (Locus 10), służącego głównie jako węzeł komunikacyjny: w ścianach południowej i północnej zlokalizowane były kolejne otwory drzwiowe, prowadzące do małego, kwadratowego pomieszczenia na południu (Locus 24), oraz do nieodkrytej jeszcze kontynuacji budowli na północy. Na podłodze pomieszczenia, również częściowo zniszczonej jamami, odkryto dolną część misy na wysokiej nóżce oraz fragmentarycznie zachowaną planszę do gry z masy gipsowej. Locus 24 , to małe pomieszczenie, w którym zlokalizowano niewielką „,szafkę” wzniesioną z cegieł i gliny. Na jego podło- 
dze znaleziono kilka kawałków złomu brązowego (w jednym przypadku był to fragment ostrza siekierki) oraz kompletny sierp z brązu, o długości $25 \mathrm{~cm}$, na którego ostrzu wyryto znak gwiazdy (ryc. 17). Taki znak, w piśmie klinowym oznaczający boga, pojawia się sporadycznie na mezopotamskich narzędziach; jego znaczenie trudno jednak zinterpretować. Wydaje się, że Locus 24 pełnił funkcję magazynu, gdzie oprócz innych dóbr przechowywano wyroby z brązu, a także złom brązowy oczekujący na przetopienie.
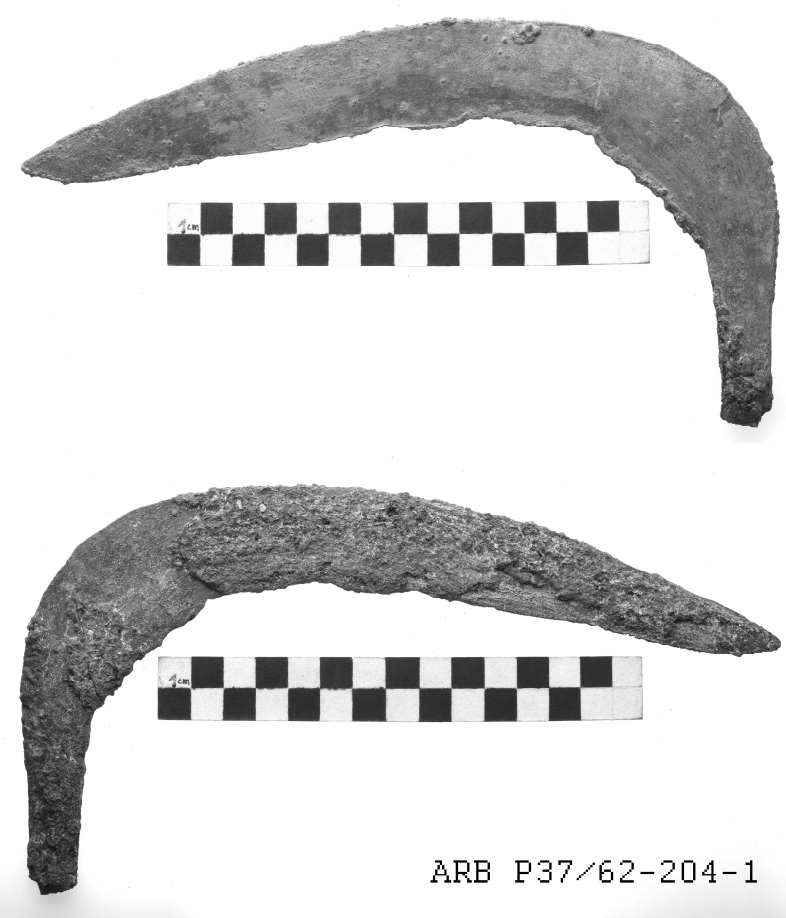

Ryc. 17. Sierp z brązu, ze znakiem „dingir”/gwiazdą wyrytą na ostrzu, okres postakadyjski, Locus $24 \mathrm{w}$ „Main Building" (fot. M. Szabłowski)

Fig. 17. Bronze sickle with a „dingir”/star sign itched on the blade, from Locus 24 in „Main Building” (photo by M. Szabłowski)

Wschodnie skrzydło „Main Building” tworzyły dwa pomieszczenia. Wejście do tego skrzydła prowadziło z dziedzińca, ale nie było zaopatrzone w próg, a tylko wyłożone brukiem podobnym do tego na dziedzińcu. Również w ścianie pomiędzy wspomnianymi pomieszczeniami znajdował się otwór drzwiowy zapewniający komunikację. Ta część „Main Building" została przebudowana w trakcie użytkowania budowli. Usunięto wówczas wschodnią ścianę Locus 13, a także mur dzielący pomieszczenia wschodniego skrzydła. W ich miejsce wzniesiono ścianę W10A, będącą przedłużeniem północnej 
ściany dziedzińca. Locus 14 zmienił kształt na prostokątny, we wschodnim zaś skrzydle zamiast dwóch pomieszczeń pozostało tylko jedno. Przebudowa dotyczyła także samego dziedzińca: wzdłuż północnej i wschodniej ściany wzniesiono ławy z ubitej gliny o szerokości ok. $20 \mathrm{~cm}$, przykrywające częściowo wcześniejszy bruk.

„Main Building” wyróżnia się spośród innych konstrukcji postakadyjskich odsłoniętych w sektorze P na Tell Arbid wysoką jakością wykonania budowli (grube tynki, wykorzystanie elementów z cegły palonej i kamienia), a także faktem, że budynek ten był użytkowany przez cały okres istnienia osady postakadyjskiej. $Z$ faktu, że inne budowle wspierają się często o jego mury można też wnosić, że jest on najwcześniejszym elementem zabudowy postakadyjskiej w tej części stanowiska. Jego przeznaczenie jest trudne do ustalenia. Obecność ceramiki kuchennej, a także żarna, moździerza i rozcieraczy z bazaltu na posadzce głównej sali (Locus 14) wskazuje jedynie na przetwarzanie produktów rolniczych i przygotowywanie żywności. Na działania związane z uprawą pól wskazuje także sierp znaleziony w pomieszczeniu magazynowym.

„Extensions”. Na zachód od „Main Buliding” odkryto pozostałości kilku mniejszych konstrukcji ${ }^{19}$, które oznaczono słowem „Extension” i kolejnymi numerami. Największa z nich, „Extension 1”, opierała się o zachodnią ścianę „Main Building” i składała się z trzech lub czterech pomieszczeń. Największe z nich, Locus $1 / 19$, mierzyło 4,35 $\times 2 \mathrm{~m}$ i miało wejście od południowego zachodu. Pozostałe, w poprzecznym układzie, znajdowały się po północnej stronie i miały ok. $3 \mathrm{~m}$ długości i poniżej 1,5 m szerokości. W dużym stopniu zniszczyły je rowy fundamentowe domów z okresu ceramiki chaburskiej i wcześniejsze od nich jamy, stąd problemy ze zidentyfikowaniem liczby pomieszczeń i ustaleniem komunikacji między nimi. Budowla „Extension 1” została wzniesiona z cegieł o takich samych wymiarach jak „Main Building”, ale wykonanych z gliny gorszej jakości i o nieco innym kolorze. Mury mają tylko 2 cegły grubości, zaś gliniany tynk nie zachował się na nich wcale. Podłogi w pomieszczeniach wykonano z gliny. Jedyną instalacją znalezioną wewnątrz budynku był niewielki piecyk ulokowany w północnej części środkowego pomieszczenia (Locus 13), co sugeruje mieszkalne przeznaczenie budowli. Obok pieca znaleziono kompletny dzbanek dekorowany plastyczną dekoracją przedstawiającą węże i skorpiony, półksiężyc i koło (być może dysk słoneczny) oraz wyryty motyw liścia palmowego (ryc. 18) ${ }^{20}$. Tego typu naczynia uznawane są zazwyczaj za utensylia kultowe. Jeśli przyjąć taką interpretację, jego obecność obok pieca w domu mieszkalnym jest trudna do wytłumaczenia. Do „Extension 1” należy też zaliczyć Locus 2A. To kwadratowe pomieszczenie otoczone murem z ubitej gliny wzniesiono tak, że zablokowało wejście do Locus 1. Jego zadaniem było być może zabezpieczenie obszernej jamy (Locus 17, średnica wlotu 0,9 m, średnica dna 1,5 m, głębokość $2,3 \mathrm{~m}$, objętość $4,8 \mathrm{~m}^{3}$ ) pełniącej być może rolę silosu.

\footnotetext{
${ }^{19}$ Po zakończeniu sezonu 2008 wydawało się, że jest to jedna budowla, ale badania prowadzone w sezonie 2009 udowodniły, że mamy do czynienia z kilkoma budynkami wznoszonymi w różnym czasie.

${ }^{20}$ Dokładnie taki sam zestaw motywów zobaczyć można na naczyniu znalezionym w postakadyjskich warstwach na Tell Brak (Mallow an 1947, s. 229, 230, Pl. LXX, 3-5).
} 

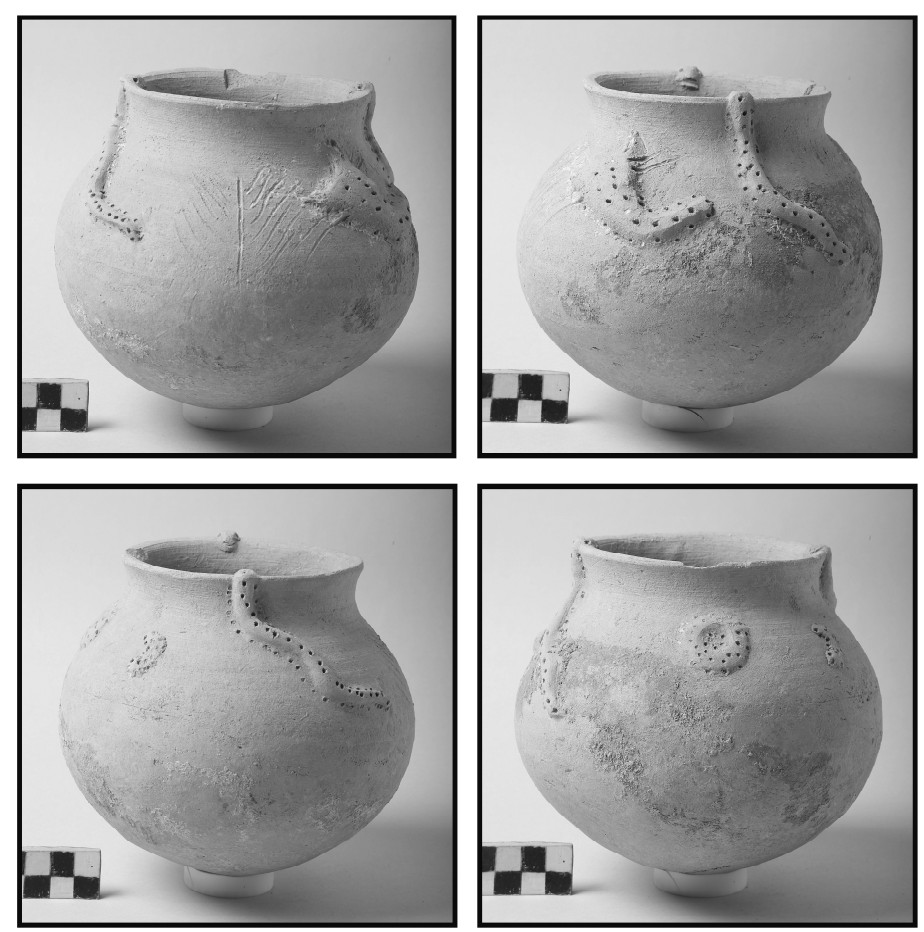

Ryc. 18. Postakadyjskie naczynie z dekoracją plastyczną (węże i skorpiony), Locus 13, „Extension I” (fot. M. Szabłowski)

Fig. 18. Post-Akkadian „,snakes \& scorpions” pot, Locus 13 of „Extension 1” building (photo by M. Szabłowski)

Budowla „Extension 2” położona była dalej na północ. Od „Extension 1” oddzielała ją niezabudowana przestrzeń o szerokości od 2 do 1,6 m (Locus 17), którą wykorzystywano jako śmietnisko (ryc. 19). Znaleziono tu znaczną liczbę fragmentów ceramiki (niektóre $\mathrm{z}$ nich, ale wyłącznie pochodzące $\mathrm{z}$ dzbanów, udało się poskładać $\mathrm{w}$ duże fragmenty naczyń), sporo kamieni różnej wielkości, pojedyncze figurki terakotowe, a także przedmioty z metalu. W większości były to małe fragmenty złomu brązowego, wśród ich znalazł się jednak uszkodzony złoty paciorek, a także kompletna łopatka do nakładania czarnego barwnika na powieki z brązu (ryc. 20). Tego typu przedmioty wchodzą w skład ,zestawów kosmetycznych” - czterech przyborów różnego typu połączonych kółkiem z drutu, znanych m.in. z cmentarzyska królewskiego w $\mathrm{Ur}^{21}$.

„Extension 2" składało się z dwóch stojących obok siebie budowli. Wschodnia, przedzielona świadkiem, nie była eksplorowana. Zachodnia natomiast miała dwie fazy: wcześniejszą, kiedy jej ściany wzniesione były z cegły i późniejszą, gdy mury wzniesiono

${ }^{21}$ Hauptmann, Pernicka 2004, zabytki 1677-1690. 


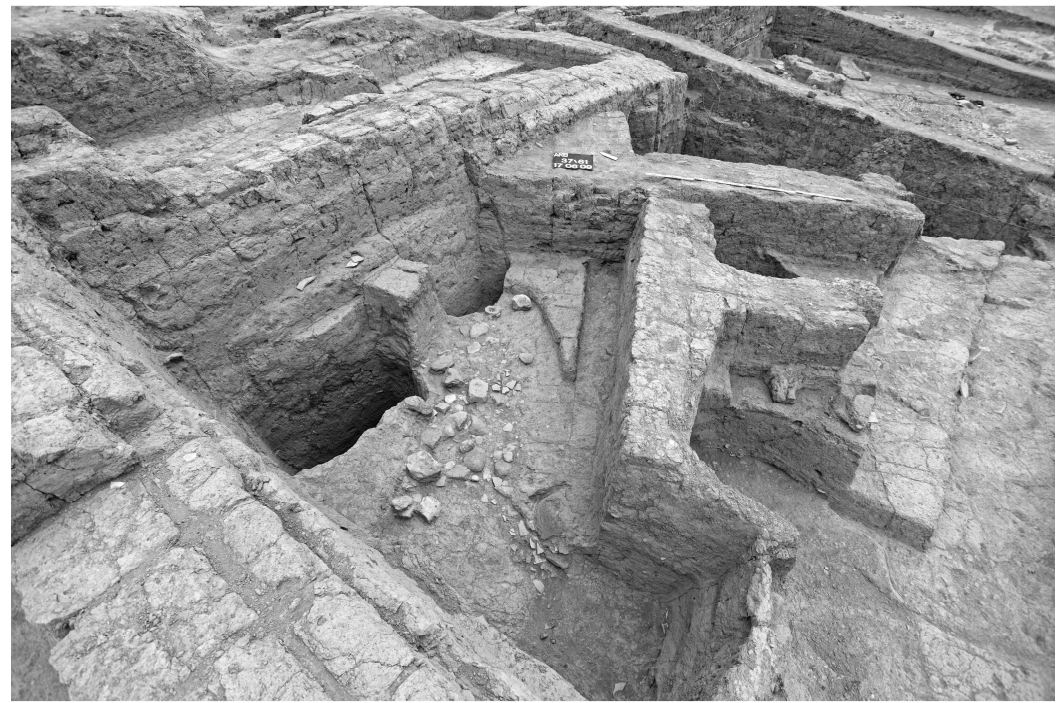

Ryc. 19. Otwarta przestrzeń (Locus 17) na północ od budowli „Extension I” (fot. M. Szabłowski)

Fig. 19. Open area (Locus 17) between „Extension 1” and „Extension 2” building (photo by M. Szabłowski)

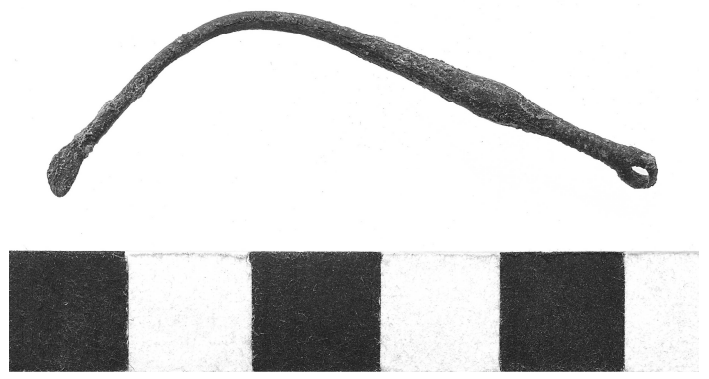

Ryc. 20. Łopatka kosmetyczna do malowania powiek, Locus 17, okres postakadyjski (fot. M. Szabłowski)

Fig. 20. A cosmetic tool (kohl-spatula) from Loc. 17, post-Akkadian period (photo by M. Szabłowski)

z ubitej gliny. Z fazą późniejszą związany jest poziom użytkowy, z którego pochodzą najciekawsze znaleziska: kolejny sierp i trzy szpile $z$ brązu oraz forma odlewnicza $\mathrm{z}$ piaskowca, służąca do wytworzenia dwóch przedmiotów $\mathrm{w}$ formie dwuzębnych widelców $^{22}$. Jej obecność, znaleziska kolejnych fragmentów złomu brązowego oraz licznych wyrobów mogą sugerować istnienie w obrębie odsłanianego kompleksu budowli warsztatu metalurgicznego, choć niekoniecznie w omawianym pomieszczeniu. W tym kontekście łatwiej zrozumieć znalezienie złomu brązowego w pomieszczeniu Locus $24 \mathrm{w}$, „Ma-

${ }^{22}$ Jak do tej pory na Tell Arbid nie znaleziono przedmiotu o tej formie. 
in Building". W ostatniej fazie istnienia osady ruiny zachodniego pomieszczenia zostały przykryte glinianą podłogą, a nad jego zachodnią ścianą wzniesiono duży piec chlebowy (średnica 1,1-1,3 m) obudowany konstrukcją z cegły mułowej ${ }^{23}$.

Prawdopodobnie kolejne budowle należące do „Extension” znajdowały się na północy (w kwadratach 36/61 i 36/62), ale niewielki stopień zaawansowania prac w tej części sektora nie pozwala rozstrzygnąć, czy odsłonięte wierzchołki murów należą do „Extension”, czy do „Main Building”.

Jak już wspomniano, taras, na którym wzniesiono budowle postakadyjskie, wcinał się częściowo w stok wzgórza, który został zabezpieczony za pomocą muru oporowego wzniesionego z dużych bloków gliny; dalej na zachód teren wznosił się zdecydowanie ku szczytowi tellu. Na zachód od „Extension 2” zniwelowany teren rozciągał się na ok. $10 \mathrm{~m}$ dalej na zachód. Nie był on jednak wykorzystany pod zabudowę; wypełniły go z czasem śmieci i popioły, a także materiał naniesiony z wyższej części tellu przez procesy erozyjne. Po kampanii 2008 r. wydawało się, że kompleks budowli postakadyjskich ogrodzony był murem również od północy, ale w 2009 r. nie udało się potwierdzić jego istnienia.

Otwarta przestrzeń położona na południe od budowli „Extension 1” wykorzystywana była przez mieszkańców kompleksu jako teren roboczy (o czym świadczą liczne po-

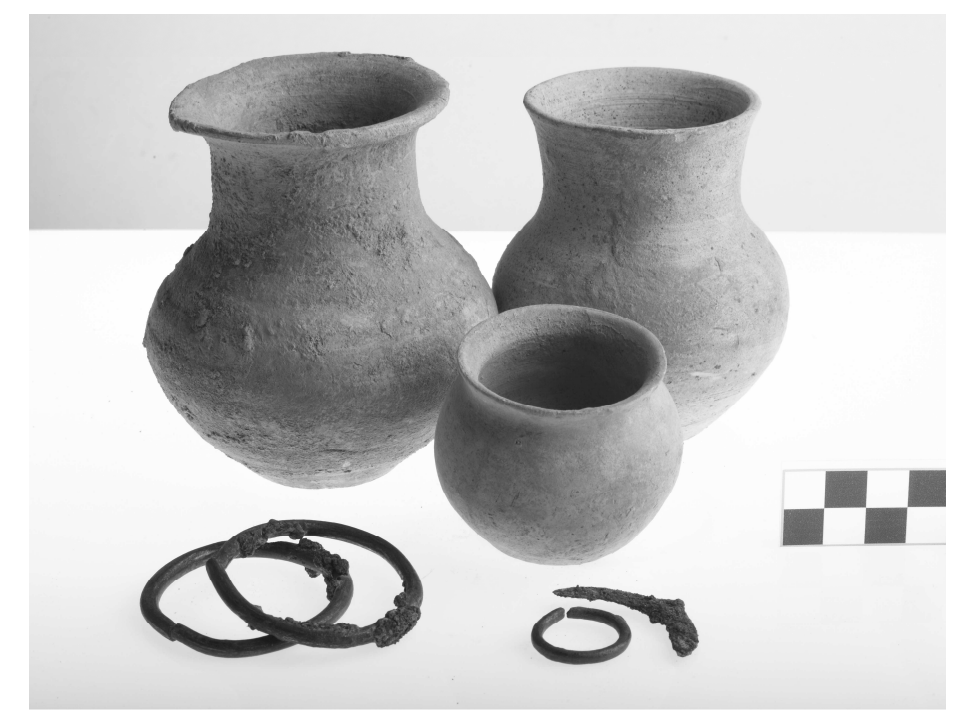

Ryc. 21. Dary grobowe z postakadyjskiego grobu G12/38/61 (fot. M. Szabłowski) Fig. 21. Burial gifts from post-Akkadian grave G12/38/61 (photo by M. Szabłowski)

\footnotetext{
${ }^{23}$ Piec eksplorowany był w $2001 \mathrm{r}$. Znaleziono w nim trzy kompletne naczynia ceramiczne (2 podstawki i dekorowany rytymi motywami garnek) oraz bazaltowy moździerz podobny do znalezionego na podłodze Locus $13 \mathrm{w}$ „Main Building”.
} 
ziomy użytkowe z ubitej gliny oraz instalacje służące do odprowadzania nadmiaru wody deszczowej). Ponadto odkryto tu duży piec chlebowy, o konstrukcji przypominającej bliźniaczo piec odkryty w $2001 \mathrm{r}$. (por. wyżej), oraz kilka niewielkich jam. Na tym terenie znaleziono też groby dziecięce. Noworodki chowano w ustawionych pionowo naczyniach ceramiki kuchennej lokowanych w jamach. Starsze dzieci (w wieku do 3 lat) układano w naczyniach ceramicznych, przy czym w jednym przypadku użyto dzbana położonego na boku (otwór ku wschodowi), a w dwóch innych złożonych ze sobą dwóch połówek dzbanów: na spodzie znajdowała się górna część naczynia ustawiona na wylewie, którą, po włożeniu ciała, przykryto czaszą z dolnej części naczynia o kulistym dnie. W jednym z takich grobów (G9/38/61) znaleziono dwie bransolety z brązu, zawieszkę wykonaną z prehistorycznej pieczęci stemplowej, cztery zawieszki $\mathrm{w}$ formie ptaków i osiem sporządzonych z muszli morskich. Jedyny grób jamowy (G12/38/61) należał do dziecka w wieku ok. 8-9 lat. Ciało ułożone było w pozycji wyprostowanej na plecach, z głową skierowaną ku zachodowi, z lekkim odchyleniem na południe. Przy głowie ustawione były trzy naczynia ceramiczne, ciało ozdabiały dwie bransolety (na przedramionach), pierścień (na lewej dłoni) i zawieszka w formie półksiężyca znaleziona pod brodą - wszystkie z brązu (ryc. 21).

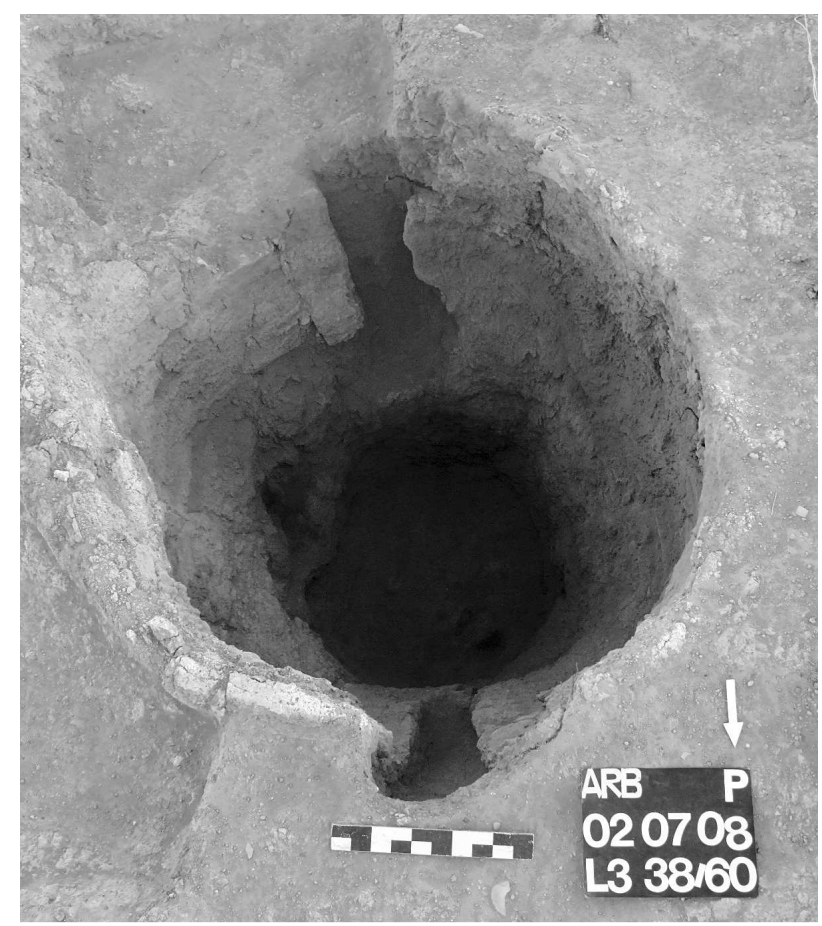

Ryc. 22. Postakadyjski piec ceramiczy odkryty w kwadracie 38/61 (fot. J. Wierzbicki)

Fig. 22. Pottery kiln of the post-Akkadian period in sq. 38/61 (photo by J. Wierzbicki) 
Piec ceramiczny. Na stoku tellu - ok. 4 m na zachód od krawędzi tarasu, na którym wzniesiono kompleks budowli z okresu postakakadyjskiego - odsłonięto pozostałości pieca ceramicznego $\mathrm{z}$ tego samego okresu. Zachowała się wyłącznie jego podziemna część, składająca się z komory ogniowej oraz komory służącej do gromadzenia popiołu w trakcie wypału ${ }^{24}$. Ta ostatnia miała ok. 1,5 m średnicy i podobną głębokość (ryc. 22). Komora ogniowa zbudowana była z cegieł suszonych i miała formę owalu o dłuższej średnicy 2,1 m i krótszej 1,8 m. Zamykała ją od dołu podłoga z gliny, która opierała się na dwóch łukowatych wspornikach. Komora ogniowa nosi ślady nasilonego działania wysokiej temperatury. Cegły użyte do budowy ścianek komory są wypalone, przy czym wewnętrzna powierzchnia jest pokryta grubą na kilka centymetrów warstwą szlaki pochodzącej z nadtopionej powierzchni cegieł. W wypełnisku pieca znaleziono głównie popioły i zawalone fragmenty konstrukcji pieca w postaci cegieł i kawałków glinianych, wewnętrznego rusztu. Znalazła się też tu niewielka liczba fragmentów ceramiki w tym szereg typowych form postakadyjskich. Ostatecznie datowanie pieca potwierdziła obecność częściowo zniekształconej w trakcie wypału miseczki postakadyjskiej.

Znaleziska luźne. W trakcie eksploracji warstw postakadyjskich napotkano wiele przedmiotów związanych $\mathrm{z}$ tym okresem, które jednak wystąpiły w przemieszanych lub przemieszczonych kontekstach i nie mogą być z tej racji powiązane bezpośrednio z użytkowaniem budowli postakadyjskich w Sektorze P. Poza licznymi fragmentami ceramiki, których nie będę opisywał, godne wspomnienia są trzy kategorie zabytków: figurki antropomorficzne, figurki zoomorficzne oraz fragmenty odcisków pieczęci cylindrycznych na glinie.

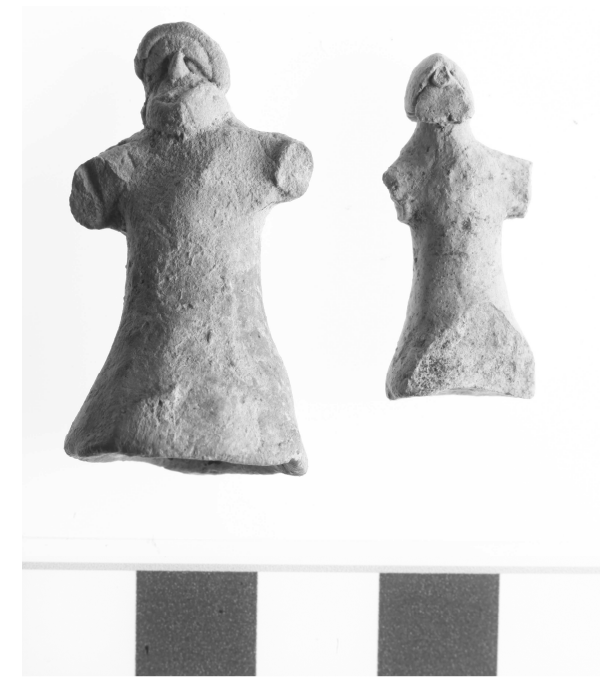

Ryc. 23. Postakadyjskie figurki terakotowe przedstawiające postaci ludzkie, kwadrat 37/60 (fot. M. Szabłowski)

Fig. 23. Post-Akkadian anthropomorphic terracotta figurines from sq. 37/60 (photo by M. Szabłowski)

\footnotetext{
${ }^{24}$ Podobny piec, datowany na okres postakadyjski odkryto na Tell Barri (Pecorella, Pierobon- Benoit 2004, s. 24, 27, 29).
} 
Wśród figurek antropomorficznych zwracają uwagę 2 zabytki znalezione w kwadracie 37/60, przedstawiające stojące postaci męskie w długich szatach, z rękami rozłożonymi na boki (ryc. 23). Czapki i brody tych miniaturowych figurek (wysokości odpowiednio 3,5 i $2,7 \mathrm{~cm}$ ) są charakterystyczne dla glinianych figurek z okresu III dynastii z Ur z południowej Mezopotamii, współczesnego okresowi postakadyjskiemu na północy.

Bardzo liczną grupę zabytków stanowią figurki zwierzęce. W sumie, podczas dwóch sezonów znaleziono ich ponad 100, z czego ok. 30 to figurki bardzo dobrze zachowane. Charakteryzuje je wysoki stopień realizmu, co pozwala identyfikować gatunki zwierząt służące za wzór. Mamy zatem jedną figurkę świni, trzy figurki psów, siedem figurek kóz i kozłów, szesnaście figurek baranów i owiec (ryc. 24) oraz sześć figurek koniowatych. Zaskakujący jest niemal całkowity brak wyobrażeń bydła.

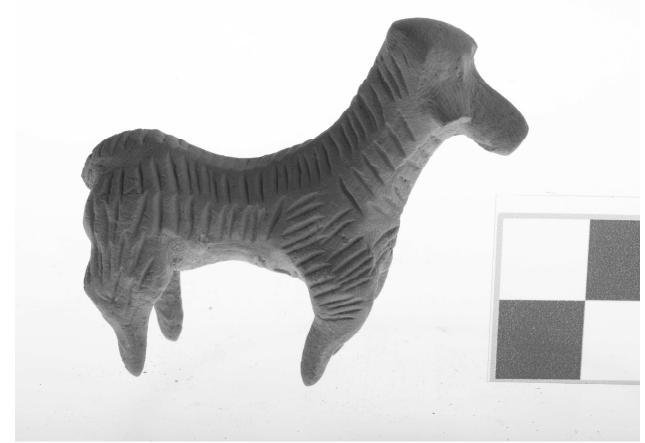

Ryc. 24. Figurka terakotowa pokazująca ostrzyżoną owcę, okres postakadyjski (fot. M. Szabłowski)

Fig. 24. A terracotta figurine showing plucked sheep, post-Akkadian period (photo by M. Szabłowski)

Ciekawą grupę znalezisk stanowią fragmentaryczne odciski pieczęci cylindrycznych na glinie pochodzące głównie z otwartej przestrzeni na południe od kompleksu budowli postakadyjskich, które na podstawie występujących motywów ikonograficznych mogą być datowane albo na koniec okresu akadyjskiego, albo na okres postakadyjski. Odciskanie pieczęci na plombach $\mathrm{z}$ wilgotnej gliny było powszechnym w Mezopotamii sposobem kontrolowania dostępu do pojemników czy pomieszczeń, zatem ich obecność może sugerować, że w kompleksie budowli prowadzone były pewne praktyki administracyjne.

\section{Znaleziska z wcześniejszych okresów (EJ I-EJ IV, ok. 2900-2150 p.n.e.)}

Najwcześniejsze pozostałości odsłonięte w czasie kampanii 2008 i 2009 r. zostały znalezione w zachodniej części sektora P. Paradoksalnie, ta część sektora leży wyraźnie wyżej niż odsłonięte budowle z okresu postakadyjskiego i chaburskiego. Taka sytuacja 
jest wynikiem prac przy tarasowaniu zbocza wzgórza, prowadzonych zarówno w okresie postakadyjskim, jak i chaburskim. W części wschodniej i centralnej wcześniejsza zabudowa została w dużej części zniszczona, natomiast ocalała na zachodzie, w zachodniej części kwadratu 38/61, gdzie odkryto część dobrze zachowanego pomieszczenia akadyjskiego, w kwadracie 38/60, gdzie poza piecem postakadyjskim napotkano pozostałości z okresu kultury Niniwa V, oraz w zachodniej części kwadratu 37/59, gdzie znaleziono mury budowli i grób z okresu akadyjskiego.

Okres akadyjski (EJ IV, 2350-2150 p.n.e.). We wschodniej części kwadratu 38/61 odsłonięto dużą część pomieszczenia zorientowanego odmiennie niż budowle postakadyjskie (Locus 11). Drzwi zlokalizowane w północnej ścianie prowadziły do wnętrza niewielkiego pokoju $(2,5 \times 2 \mathrm{~m}$ w odsłoniętej części), z płaskim paleniskiem na podłodze, obok którego znaleziono pozostałości ceramicznego dzbana i dwóch czarek. Forma naczyń pozwoliła wydatować pomieszczenie na okres akadyjski.

Pozostałości z tego okresu odkryto także w kwadracie 37/59. Odsłonięto tam narożnik pomieszczenia, którego ściany wkopano częściowo we wcześniejszą warstwę, z tego powodu jego poziomy użytkowy nie zachował się. Na zewnątrz wspomnianego pomieszczenia odkryto grób jamowy (G1/37/59), w którym znaleziono dwa małe dzbanki oraz dłuto z brązu. Pozostałości szkieletu zachowały się jednak w tak złym stanie, że niemożliwa była rekonstrukcja jego układu w grobie.

Okres kultury Niniwa V (EJ I-II, ok. 2900-2600 p.n.e.). Pozostałości konstrukcji z tego okresu napotkano przede wszystkim w kwadracie 38/60, w południowo-zachodnim narożniku sektora. Stwierdzono tu występowanie charakterystycznej dla tego okresu brązowo-czerwonej cegły mułowej niskiej jakości oraz ceramiki Niniwa V. Ponieważ celem projektu było badanie późniejszych okresów, badania w tym kwadracie zostały zatrzymane. Jedynym wyeksplorowanym obiektem był grób G1/38/60. Zawierał on kości dziecka w wieku 5-7 lat, jeden paciorek z kamienia oraz czarkę ceramiki Niniwa V.

Ważną grupę znalezisk z tego kwadratu stanowią odciski pieczęci cylindrycznych na glinie, reprezentujące przede wszystkim tzw. Piedmont Style, typowy dla okresu Niniwa V. Wiele odcisków tego typu zostało znalezionych na Tell Arbid w sektorach D i W, gdzie badana była zabudowa $\mathrm{z}$ tego okresu. Z kwadratu 37/60 pochodzi też kompletna pieczęć cylindryczna $\mathrm{z}$ alabastru, zdobiona motywem rombów. Analogiczną pieczęć znaleziono w Mari nad Eufratem, gdzie datowana jest ona na okres $2900-2750$ p.n.e. ${ }^{25}$

\section{PODSUMOWANIE}

Po dwóch sezonach prac polowych można stwierdzić, że decyzja o podjęciu badań w Sektorze P była uzasadniona. Co prawda pozostałości z okresu chaburskiego okazały

${ }^{25}$ Parrot 1956, no. 586, pl. 67. 
się znacznie bogatsze niż oczekiwano, ale odkrycia dotyczące cmentarzysk oraz lepsze poznanie architektury grobowej przyniosło szereg ustaleń, które zmieniają konkluzje zaprezentowane w monograficznej pracy doktorskiej dotyczącej tego zagadnienia ${ }^{26}$. Trzy wyjątkowo dobrze zachowane groby komorowe pozwalają lepiej zrozumieć funkcjonowanie tego typu grobowców, a także wytyczyć linię rozwojową pomiędzy konstrukcjami jakie rozpoznano na Tell Arbid, a średnio- i nowoasyryjskimi grobami komorowymi np. z Aszur ${ }^{27}$.

Eksploracja warstwy postakadyjskiej przyniosła również interesujące rezultaty, choć postęp prac był wolniejszy niż zakładano, przede wszystkim z powodu konieczności uważnej eksploracji wspomnianych wcześniej grobów. Odsłonięto dużą część kompleksu architektonicznego o unikatowej formie. Wyróżnienie kilku stref architektonicznych (,Main Building”, „Extensions”, otwarty teren z instalacjami) odpowiada zapewne różnym strefom aktywności w obrębie tego kompleksu, choć jak do tej pory przyporządkowanie określonych funkcji do poszczególnych jego części jest trudne. Nie ulega wątpliwości, że w odsłanianej budowli realizowane były różne cele. Bez wątpienia przechowywano tu i przetwarzano produkty rolnicze. Świadczy o tym obecność narzędzi rolniczych (dwa sierpy), żaren i moździerzy do obróbki ziarna oraz pieców chlebowych do wypieku chleba. Ceramika kuchenna, używana do gotowania potraw, sugeruje, że część pomieszczeń pełniła funkcję mieszkalną. Trzy groty krzemienne oraz znalezisko glinianych pocisków do procy sugerują, że polowano na dzikie zwierzęta zamieszkujące step, co zapewne uzupełniało dietę proteinową, której podstawą były zwierzęta hodowlane (vide liczne figurki zwierzęce). Obecność licznych fragmentów złomu brązowego oraz forma odlewnicza sugerują, że na miejscu istniał warsztat metalurgiczny, w którym przetapiano złom i wytarzano przynajmniej część niezbędnych narzędzi. Wreszcie, piec ceramiczny zlokalizowany na zboczu na południowy zachód od kompleksu wskazuje, że ceramikę, jaka była używana przez jego mieszkańców, przynajmniej w części wytwarzano lokalnie. Kształty naczyń i ich dekoracja przypominają przede wszystkim ceramikę postakadyjską z Tell Brak $^{28}$, stanowiska leżącego ok. $25 \mathrm{~km}$ na południe od Tell Arbid. Pojedyncze znaleziska odcisków pieczęci cylindrycznych na plombach glinianych nie pozwalają stwierdzić, czy związane z ich użyciem czynności administracyjne wykonywano na stanowisku. Nie można wykluczyć, że trafiły one na Tell Arbid wraz z opakowaniami transportowanych produktów, co wydaje się sugerować fakt, że do tej pory nie znaleziono dwóch odcisków tej samej pieczęci. Komentarza wymaga także znaczna liczba wyrobów z brązu, znalezionych zarówno w budowlach, jak i w grobach postakadyjskich, znacznie większa niż liczba takich znalezisk w warstwach z okresu Niniwa $V$ (1. poł. III tysiąclecia p.n.e.) lub okresu ceramiki chaburskiej (1. poł. II tysiąclecia p.n.e.). Można zaryzykować twierdzenie, że mamy tu do czynienia z budowlą/osadą,

\footnotetext{
${ }^{26}$ Wygnańska 2006, 2012.

${ }^{27}$ Haller 1954.

${ }^{28}$ Oates 2001 , s. $170-177$.
} 
która w znacznym stopniu musiała być samowystarczalna i stosunkowo zamożna. Być może jej zamożność wynikała z położenia na szlaku między dwoma najważniejszymi miastami regionu: Urkesz (Tell Mozan) na północy i Nagar (Tell Brak) na południu.

\section{Cele na sezon 2010}

Najważniejszym zadaniem na sezon 2010 jest dokończenie eksploracji kompleksu postakadyjskiego. W południowej części sektora prace obejmować będą przede wszystkim usunięcie zadokumentowanych wcześniej świadków między kwadratami 37/61 a 38/61,37/61 a 37/61 oraz 36/62 a 37/62. W ten sposób znikną wysokie niekiedy na niemal dwa metry ostańce nawarstwień, które dzielą pomieszczenia postakadyjskie, w niektórych przypadkach na części zbyt małe, by można je było efektywnie eksplorować. Usunięcie świadków powinno także pozwolić uzupełnić plany budowli, które wcześniej były częściowo rekonstruowane.

Głównym terenem eksploracji będzie północna część sektora, gdzie w 2009 r. w kilku miejscach odsłonięto wierzchy murów postakadyjskich. Konieczne będzie rozebranie dość mocno zerodowanych murów domów chaburskich i ewentualnych ich fundamentów. Przeprowadzenie tych działań pozwoli ustalić jak przebiegała północna granica „Main Building” i czy od tej strony również wzniesiono konstrukcje należące do „Extensions". Wreszcie, na wschodzie, wznowione zostaną badania w kwadracie 37/63, w nadziei zidentyfikowania wschodniego krańca zabudowy postakadyjskiej.

Prace w warstwie chaburskiej ograniczą się, jak wspomniano, do rozbiórki murów należących do leżącego na północy Domu I. Niewykluczone, że przy tej okazji zostaną odkryte kolejne groby. Dokończenia eksploracji wymaga także komora grobowa obiektu G2/35/61. Wreszcie, na dnie szybu prowadzącego do grobu komorowego G1/35/61 zauważono ścianki kolejnego pieca ceramicznego. Planowany w tym miejscu sondaż ma na celu wyjaśnienia z jakim okresem wiąże się ta struktura oraz zbadanie i zadokumentowanie jej konstrukcji.

\section{BIBILIOGRAFIA}

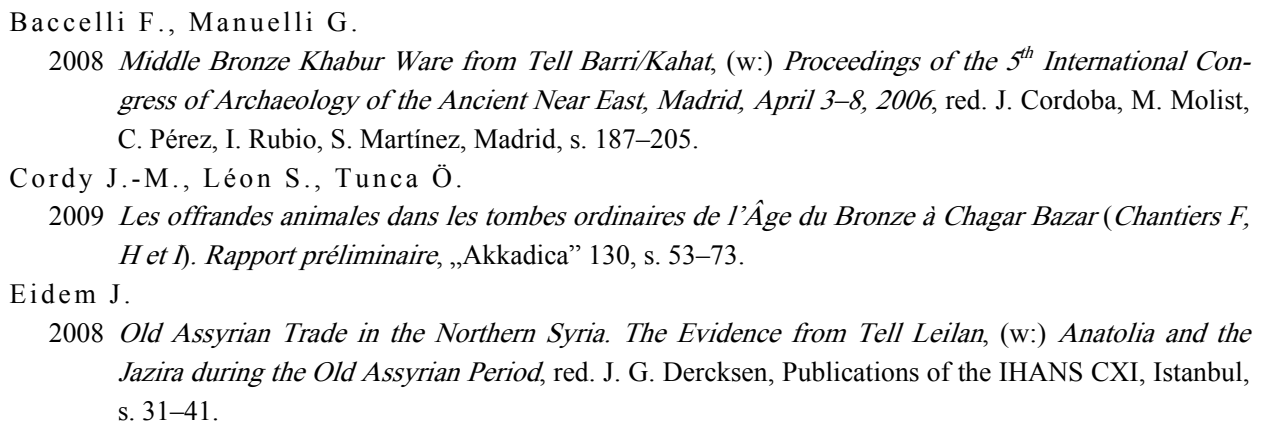
gress of Archaeology of the Ancient Near East, Madrid, April 3-8, 2006, red. J. Cordoba, M. Molist, C. Pérez, I. Rubio, S. Martínez, Madrid, s. 187-205.

Cordy J.-M., Léon S., Tunca Ö.

2009 Les offrandes animales dans les tombes ordinaires de l'Âge du Bronze à Chagar Bazar (Chantiers F, H et I). Rapport préliminaire, „Akkadica” 130, s. 53-73.

Eidem J.

2008 Old Assyrian Trade in the Northern Syria. The Evidence from Tell Leilan, (w:) Anatolia and the Jazira during the Old Assyrian Period, red. J. G. Dercksen, Publications of the IHANS CXI, Istanbul, s. $31-41$. 
Haller B.

1954 Gräber und Grüfte von Assur, „Wissenschaftlische Veröffentlischungen des Deutschen Orient Geselschaft", Bd. 65, Berlin.

Hauptmann H., Pernicka E.

2004 Die Metallindustrie Mesopotamiens von den Anfangen bis zum 2. Jahrtausend v. Chr., Orientalische Archäologie, Bd. 3, Rhaden.

Koliński R.

2007a Sir Max Mallowan Excavations at Tell Arbid in 1936, „Iraq” 69, s. 73-115.

2007b The Upper Khabur Region in the Second Part of the Third Millennium BC, „Altorientalische Forschungen" 34/2, 2007, s. 342-69.

Mallowan M. E. L.

1937 The Excavations at Tell Chagar Bazar, and an archaeological survey of the Habur region. Second Campaign, 1936, „Iraq” 4, 1937, s. 91-177.

1947 Excavations at Brak and Chagar Bazar, „Iraq” 9, s. 1-259.

Oates J.

2001 The Third Millennium Pottery, (w:) Excavations at Tell Brak, vol. 2: Nagar in the third millennium $B C$, red. D. Oates, J. Oates, H. McDonals, Cambridge, s. 151-194.

Parrot A

1956 Le Temple de Ishtar, Mission Archéologique à Mari, vol. I, Paris.

Pecorella P., Pierobon-Benoit R.

2004 Tell Barri/Kahat. La campagna del 2001, Relazione preliminare, Firenze.

Piątkowska-Małecka J., Wygnańska Z

2006 Szczątki zwierzęce z grobowca chaburskiego na stanowisku Tell Arbid (Syria) jako przejaw wierzeń i rytuałów pogrzebowych, (w:) Zwierzę jako sacrum w pradziejach i starożytności. Zbiór studiów, red. L. Kostuch, K. Ryszewska, Kielce, s. 77-99.

Rutkowski $\ell$.

2006 Górna Mezopotamia na przełomie III i II tysiąclecia p.n.e. Analiza postakadyjskiego materiału ceramicznego z Tell Arbid, maszynopis pracy doktorskiej, Instytut Archeologii Uniwersytetu Warszawskiego.

Wygnańska Z.

2006 Obrządki grzebalne i związane z nimi rytuały w Mezopotamii i Syrii północnej w pierwszej połowie II tysiąclecia p.n.e., maszynopis pracy doktorskiej, Instytut Archeologii Uniwersytetu Warszawskiego.

TWO SEASONS OF EXCAVATIONS AT TELL ARBID (NORTH-EAST SYRIA), 2008-2009

\section{Sum mary}

A three-year long field research program was undertaken at the site of Tell Arbid (North-East Syria) by a team of the Institute of Prehistory, Adam Mickiewicz University. Its aim was the exploration of post-Akkadian levels of the site, whose history encompasses three millennia (from the beginning of the $3^{\text {rd }}$ till the end of the $1^{\text {st }}$ millennium BC) (Tab. 1). Two field seasons, carried out in Sector P in the Summer of 2008 and in the Spring of 2009 yielded not only numerous finds of the post-Akkadian period, but also a considerable number of later graves, dating to the MBA, or Khabur Ware period (XVIII-XVII cent. BC).

The MBA levels, which were partly preserved over the post-Akkadian complex, were to a large extent damaged by erosion (Fig. 3). Only in the eastern part of the excavated Sector rela- 
tively well preserved mud-brick walls could be cleared. This good state of preservation resulted from the fact that the house discovered there was located on a terrace whose surface was ca. $1 \mathrm{~m}$ lower than the floors of other houses (Fig. 4). In the remaining part of the Sector, mud brick walls did not survive and the outlines of structures were reconstructed only based on the presence of foundations of beaten clay (pise). Numerous tombs contemporary to the MBA houses were identified during the two seasons of work; they were usually dug into the surface of the tell around the houses - only graves of very small children were located within houses (Tab. 2). Graves could be divided into three categories: chamber graves, cist graves and shaft graves.

Chamber graves (four examples identified) were family burials composed of a chamber covered with a brick vault and a shaft leading to the chamber (Fig. 5). They usually yielded bones of more than one person, but, as most of them seem to have been robbed already in Antiquity, not many grave goods were found. In this respect, grave G7/37/62 was exceptional. It avoided plundering and yielded a relatively rich set of burial gifts, including nearly 10 pottery vessels, a bronze axe and three daggers/spearheads, as well as a rich set of jewellery including over 300 beads of semi-precious stones, shell, bone, and frit, two pins, a bracelet and pincers of bronze as well as other goods (Fig. 7-8).

Cist graves (five examples), were composed of a chamber enclosed from three sides with mud-brick walls and closed from the top by a row of bricks set either at a side or corner. They were used for single burials accompanied by one or two vessels, a bronze pin and, occasionally, some beads (Fig. 10-11).

Shaft graves where used mainly to bury children. They fall into two subcategories: pot-graves and pit inhumations. In the first variant (6 examples) a pottery vessel used as a container for a body was located in a niche cut into one of the walls of the shaft. Some of these graves turned out to contain rich sets of pottery - in the case of G5/36/62 the set consisted of 13 pottery vessels (Fig. 12). An exceptional shaft grave (G1/37/62) held the remains of at least four children aged 2.5 to 4.5 years, and contained, besides seven vessels and some beads, a cylinder seal (dating to the mid $3^{\text {rd }}$ millennium BC) used as an amulet (Fig. 13). The other variant is represented by 4 graves. A body (or bodies) was deposited at the bottom of the shaft. Graves of this group are very modest as far as grave goods are concerned - only one of them contained a miniature jug of the Khabur Ware. This kind of vessel seems to be typical of child graves at Arbid, as at least one example of such a vessel was found in each child grave which contained pottery.

The main structure excavated in the post-Akkadian level is an extensive building complex composed of three functional areas (Fig. 14). The core of the complex consists of the „Main Building". Up to date, three rooms and a stone-paved courtyard belonging to this building were excavated, but it obviously continues towards the North and East. In one of the rooms, a complete bronze sickle was found (Fig. 17), while the courtyard and the main hall of the building yielded numerous pottery sherds, of which some complete vessels could be reconstructed. Towards the West, more buildings were discovered, constructed against the wall of the „Main Building”. They belong to two separate structures („Extension 1" and „Extension 2”), which were at least once reconstructed during the post-Akkadian period. From „Extension 1”, an intact pot decorated with applications representing snakes and scorpions (Fig. 18), adornments typical for the post-Akkadian period, was found. „Extension 2” yielded evidence of possible metallurgical production at the site: another bronze sickle, a few pins and a casting mould of sandstone. A narrow area located between „Extension 1" and „Extension 2" was used for waste disposal; numerous stones and pottery fragments were found there. Among those, some more exceptional finds were identified: a bronze 
cosmetic-tool in the form of a spatula (Fig. 20), a few animal figurines and a fragmentary human figurine. Towards the South, an open area existed that was used for some household activities, as attested by numerous usage levels of stamped clay and a large bread oven. In this area, some postAkkadian graves were identified (Fig. 21). Further towards the west, the built-up area was limited by a retaining wall supporting earlier deposits, forming the highest part of the site. Into these strata a circular pottery kiln of a post-Akkadian date was dug-in. It was nearly $2 \mathrm{~m}$ in diameter and its preserved subterranean part, composed of a fire-chamber and a chamber for ashes, was preserved to a depth of nearly $2 \mathrm{~m}$ below the present surface of the ground (Fig. 22).

Two seasons of fieldwork in Sector P at Tell Arbid considerably increased the knowledge of burial customs of the Middle Bronze Age North Mesopotamia. The relatively large number of excavated graves ( 25 by the UAM mission plus 12 graves excavated previously by the team of the Warsaw University in the same area) must be related to the cluster of five or six houses of the same period located on the eastern slope of the tell which allows for inquiries into the relations between the living and their dead. The post-Akkadian architectural complex provided new information on the nature of this period settlement at Tell Arbid. It turned out to be relatively rich and self sustained, as proven by the presence of agricultural tools, storage jars, tools and installations for food production as well as remains hinting at the presence of pottery and metal-casting workshops. Its wealth most likely resulted from a position on the road linking two main cities of the region, serving as seats of local kings: Nagar (Tell Brak) in the South and Urkesh (Tell Mozan) in the North. It constituted a part of a trade road linking Mesopotamia with Anatolia through the Mardin pass, located only a dozen kilometres from Urkesh. 